University of Maryland Francis King Carey School of Law

DigitalCommons@UM Carey Law

\title{
What Difference Does ADR Make? Comparison of ADR and Trial Outcomes in Small Claims Court
}

Lorig Charkoudian

Deborah Thompson Eisenberg

University of Maryland Francis King Carey School of Law, deisenberg@law.umaryland.edu

Jamie Walter

Follow this and additional works at: https://digitalcommons.law.umaryland.edu/fac_pubs

Part of the Dispute Resolution and Arbitration Commons

\section{Digital Commons Citation}

Charkoudian, Lorig; Eisenberg, Deborah Thompson; and Walter, Jamie, "What Difference Does ADR Make? Comparison of ADR and Trial Outcomes in Small Claims Court" (2017). Faculty Scholarship. 1585.

https://digitalcommons.law.umaryland.edu/fac_pubs/1585

This Article is brought to you for free and open access by the Francis King Carey School of Law Faculty at DigitalCommons@UM Carey Law. It has been accepted for inclusion in Faculty Scholarship by an authorized administrator of DigitalCommons@UM Carey Law. For more information, please contact smccarty@law.umaryland.edu. 


\title{
What Difference Does ADR Make?
}

\section{Comparison of ADR and Trial Outcomes in Small Claims Court}

\author{
Lorig Charkoudian \\ Deborah Thompson Eisenberg \\ Jamie Walter*
}

This study compares the experience of small claims litigants who use alternative dispute resolution ("ADR") to those who proceeded to trial without ADR. ADR had significant immediate and long-term benefits, including improved party attitudes toward and relationship with each other, greater sense of empowerment and voice, increases in parties taking responsibility for the dispute, and increases in party satisfaction with the judiciary. Cases that settled in ADR also were less likely to return to court for an enforcement action within the next year.

\section{INTRODUCTION}

Many courts offer alternative dispute resolution (ADR) processes, such as mediation and settlement conferences, but few rigorous studies have examined what difference ADR makes as compared to trial. This research is the first to compare the attitudes and changes in attitudes of litigants who participated in ADR to an equivalent comparison group who used the traditional court process, both immediately and three to six months later. The research measured a variety of litigant attitudes including: attitudes toward the other party, sense of empowerment and voice in the process, sense of responsibility for the dispute, belief that the conflict could be or had been resolved, and satisfaction with the judicial system. These attitudes were tracked from before to

\footnotetext{
*This research is connected to a broader study of the costs and benefits of ADR in Maryland courts conducted by the Maryland Judiciary Administrative Office of the Courts, with funding by the State Justice Institute, in collaboration with Community Mediation Maryland, Bosserman Center for Dispute Resolution at Salisbury University, the Institute for Governmental Service and Research, University of Maryland, College Park, and the University of Maryland Francis King Carey School of Law Center for Dispute Resolution. The authors thank the research team, judges, judicial staff, ADR practitioners, and litigants for all of their cooperation, assistance, and support. Caroline Harmon Darrow drafted portions of the original literature review and Haleigh LaChance drafted portions of the research report from which this article was drafted. Additional information about the larger Maryland ADR study is available at http://mdcourts.gov/courtoperations/adrprojects.html.
} 
after the ADR session or trial as well as three to six months later. The study also tested whether experiences differed for various demographic groups. Finally, the study examined the predicted probability that the treatment and comparison groups would return to court for an enforcement action in the subsequent year.

Many ADR studies rely on the results of post-ADR participant evaluation forms, without conducting surveys prior to the intervention, using a comparison group that went to trial without ADR, or controlling for other variables that could affect the outcome. The present study measures the immediate and long-term attitudes and changes in attitudes of those litigants who participated in ADR as compared to those who went to trial without ADR. Unlike most ADR research, the study took into account that there may be a range of other factors that could explain shifts in party perspectives. We gathered a wide range of information about the parties and the conflict and, using regression analysis, controlled for other factors that might influence the outcome. This permits more statistically rigorous conclusions about the impact of ADR as compared to trial.

Uniquely, this study tests whether there is value in simply participating in the ADR process, regardless of whether the parties reach agreement. Many judicial assessments of ADR focus on settlement rates and trial avoidance as the main goals of ADR (Anderson \& Pi, 2004; Goerdt, 1992). To evaluate the impact of ADR participation beyond settlement, we included parties who reached agreement in ADR and those who did not. In addition, some commentators question the value of ADR because parties can negotiate directly with each other and settle on their own "on the courthouse steps." (Wissler, 2002). The comparison trial group therefore included those who reached "hallway" agreements before trial and those who did not. The regression analysis included a variable for those who reached agreement, whether in ADR or on 
their own through unassisted negotiation. This variable isolated the impact of simply participating in the ADR process, regardless of whether the parties settled.

We report outcomes that are statistically significant at a 95\% confidence level. Using this heightened benchmark, ADR has significant positive impacts in both the short-term and longterm, regardless of whether the parties settle. In the short-term, ADR improves the parties' attitudes toward each other, gives parties a greater sense of empowerment and voice in the process, increases their taking of responsibility for the dispute, and increases their satisfaction with the judicial system more generally. In the long-term, ADR participants are more likely than those who went to trial to report an improved relationship with and attitude toward the other party, satisfaction with the outcome, and satisfaction with the judiciary. Parties who reach agreement in ADR are less likely to return to court for an enforcement action than all other cases (including those in which the parties settled on their own without any ADR, ADR cases that did not settle, and cases with a court verdict).

\section{LiterATURE REVIEW}

Studies of ADR in civil cases have identified many benefits for the parties and the judiciary (Shack, 2003, 2007; Stipanowich, 2004). In the short term, ADR generally promotes high settlement rates and judicial efficiency (Clarke, Ellen \& McCormick, 1995; Clarke, Valente \& Mace, 1992; Goerdt, 1992; Hann \& Barr, 2001; Pearson \& Thoennes, 1984; Slack, 1996; Wissler, 2004). Mediation saves time and resources for the parties and courts (Anderson \& Pi, 2004; Bundagg \& Flagg, 2003; Clarke, Ellen \& McCormick, 1995; Clarke \& Gordon, 1997; Clarke, Valente \& Mace, 1992; Goerdt, 1992; Hann \& Barr, 2001; Kobbervig, 1991; MacFarlane, 1995; Slack, 1996; Thoennes, 2000; Wissler, 1995). 
Most ADR studies report high levels of party satisfaction (Kobbervig, 1991; Maiman, 1997; McEwen, 1992; Schildt, Alfini \& Johnson, 1994; Slack, 1996). ADR participants generally believe that the process and outcome are fair (Hann \& Barr, 2001; Maiman, 1997; Shack, 2003; Wissler, 2002). Some studies have found that parties report greater perceptions of fairness and satisfaction with mediation than they do with adjudication. (Wissler 2004, p. 58-59, 65). This is true regardless of settlement in mediation (Wissler, 1995, p. 351).

Improved relationships between parties are an oft-touted benefit of ADR, because mediation can "permit a more complete airing of grievances and improve relationships between disputants" (Pearson, 1982, p. 440). But rigorous research demonstrating relational shifts in mediated cases is limited. In examining four studies of general civil mediation, Wissler found that "a minority of litigants (from 5 to 43 percent) thought that mediation improved their relationship with the other party" $(2004$, p. 67). Participants and attorneys in civil mediation in Ohio courts indicated that mediation gave them more clarity about their own cases (in roughly half the cases) and created more understanding of the other party's views ( $70 \%$ of cases). A third of attorneys indicated that mediation helped the parties' relationship with each other and attorney’s relationship with opposing counsel (Wissler 2002, p. 664).

Research about the parties' relationship with each other post-mediation is mixed. In one study, parties were as likely to report that mediation had not improved their relationship with the other side as they were to report that it had (Maiman, 1997). In small claims court, those choosing mediation reported "improved post-court attitudes toward and understanding of the other party" (Wissler 1995, p. 351). In mediations that did not end in settlement, however, parties had a more negative assessment of each other after the mediation as compared to before the 
process. Some studies suggest that trial has a more negative impact on the parties' underlying relationship than mediation (McEwen \& Maiman, 1981; Wissler, 1995).

Some studies have found that mediation participants are more likely to comply with a mediated agreement than a court ruling (Wissler 2004, p. 60). McEwen and Maiman (1981) found a much higher rate of payment by small claims defendants who used mediation as compared to adjudication, both when parties settled in mediation and when they returned to court for final disposition. Other studies examining the durability of mediated agreements have found compliance rates ranging from $59 \%$ to $93 \%$ (Hedeen, 2004; Wissler, 2004). In contrast, one study found that compliance in mediated cases was only "marginally greater" than in adjudicated cases (Wissler 1995, p. 351).

Even when mediation does not result in agreement, ADR participants report a preference for future ADR use. Two studies of small claims mediation programs found that "almost twice as many litigants who went to trial after not settling in mediation said they would prefer to use mediation rather than trial in a future case" (Wissler 2004, p. 58). In the only multi-court study of litigants' ex ante procedural preferences (after the case was filed but before resolution), litigants ranked mediation, a judge trial, and negotiation with clients present as equally preferred procedures, with no statistically significant differences among these preferences (Shestowsky, 2014).

Research about the longer-term outcomes of civil ADR is a major gap in the literature (Wissler, 2002, p. 695). Generally, mediation can lead to better compliance with the outcome, fewer future court filings, increased use of ADR in the future, and decreased reliance on the police and other public resources (Charkoudian, 2005, 2010; Shepherd, 1995; Wissler, 2002). 


\section{RESEARCh DESIGN AND Methodology}

\section{Overview of Data Collection Process}

The study compares the immediate and long-term attitudes and changes in attitudes of litigants who used day of trial ADR (the "treatment" group) to an equivalent group who proceeded to trial without ADR ("comparison" group). The study focused on civil cases in the District Court of Maryland, a statewide unified court that has jurisdiction over a variety of contract, tort, return of property (replevin and detinue), and landlord-tenant claims (tenant holding over, breach of lease, and wrongful detainer).

The District Court of Maryland ADR program offers mediation or settlement conferences at no charge to litigants on the day of their trials through a roster of volunteer mediators and settlement conference attorneys, collectively called "ADR practitioners."1 The type of process provided depends upon the expertise of the volunteer ADR practitioner present that day. Most ADR practitioners in the study indicated that they were providing mediation (88\%) with the remaining $12 \%$ providing a settlement conference. Prior studies have shown that mediators who profess to practice a particular framework or orientation of mediation may vary in the strategies they use during the session (Riskin, 1994). Thus, the actual techniques used by mediators or settlement conference attorneys may be similar in some ways. ${ }^{2}$

Treatment cases were recruited from the small claims civil dockets in Baltimore City and Montgomery County. To control for selection bias, comparison cases were selected from these

\footnotetext{
${ }^{1}$ Mediation is "a process in which the parties work with one or more impartial mediators who, without providing legal advice, assist the parties in reaching their own voluntary agreement for the resolution of the dispute or issues in the dispute." (Maryland Rule 17-102.) At a settlement conference "the parties, their attorneys, or both appear before an impartial person to discuss the issues and positions of the parties in the action in an attempt to resolve the dispute or issues in the dispute by agreement or by means other than trial" (Maryland Rule 17-102). Unlike mediators, settlement conference attorneys "may recommend the terms of an agreement" (Maryland Rule 17-103(1)).

2 Another portion of this study involved observation of the ADR sessions and behavioral coding of the specific strategies used by the ADR practitioner. This research aimed to determine which specific interventions by the ADR practitioners led to particular outcomes. (Charkoudian, Eisenberg \& Walter, 2017).
} 
same dockets, on days when an ADR practitioner was not present, using the same criteria that would have been used to refer cases to ADR in that jurisdiction. Individuals in the trial group were offered a $\$ 10$ gift card to incentivize participation. Because ADR is a voluntary process, the court ADR program did not want the researchers to offer ADR participants a gift card on the day of trial, as it may have skewed incentives for participation in ADR. (Both groups were offered a \$10 incentive check for participating in the long-term study below.)

The researchers used questionnaires to interview the parties immediately prior to, and at the conclusion of, the ADR session or trial. The parties were separated for these interviews so they could not hear each other's responses. If the parties did not reach agreement in ADR, they returned to the courtroom for their trial and researchers administered the post-process questionnaire after the trial. Prior to the launch of the study, researchers pilot-tested the questionnaires for length and clarity, first with ADR program managers and then with participants in day-of-trial mediation. In addition to capturing demographic information, the questionnaires asked for the parties' opinions about the conflict, the other party, the court, their goals, the process, and the outcome, using a scale of "strongly agree, agree, neither agree nor disagree, disagree, and strongly disagree."

If all parties agreed to participate in the study, researchers conducted guided interviews with plaintiffs, defendants, and any support people who attended with parties. Support people were included because evidence suggests that they could be key players in the conflict or influential to the outcome. This data set included surveys from five people who were support people for plaintiffs and 14 people who were support people for defendants. Of the plaintiffs and defendants who had support people present and answered these questions (total of 13), the average answer for how much they were affected was 1.7 and the average answer for how much 
they were influential was $1.5 .^{3}$ Researchers also interviewed attorneys who represented the parties, using a questionnaire that was similar to the party survey. Attorney surveys were not included in the analysis because they did not measure attitudes toward the other party or demographic information. ${ }^{4}$

Three months after the intervention, researchers called participants for follow-up interviews to measure changes in attitudes and gather information about how the outcome was working. After five attempted calls, the researchers deemed the participant unreachable. Of the 402 participants contacted, 166 were reached for follow up. The typical timing of the completed call was three months after the intervention and the average length of time between the intervention and follow up call was 4.3 months (standard deviation of 1.57), with a minimum of 2.1 months and maximum of 11.4 months.

Twelve months after the trial date, researchers reviewed court records to determine if the parties returned to court for any type of enforcement action. This included any request for enforcement of the judgment, post-judgment appeal or motion for reconsideration, as well as petitions for warrant of restitution, writ of garnishment of wages, motion to vacate dismissal, motion to vacate judgment, motion for new hearing, recordation of a circuit court lien, petition for de novo appeal, and motion to re-open case. This data was used in the case level analysis.

\section{SHORT-TERM IMPACT OF ADR}

\section{Data Set}

Table 1 provides the descriptive and summary statistics for each variable in the shortterm participant level data. $\mathrm{N}$ is the number of people for whom data exists for that variable.

\footnotetext{
${ }^{3}$ Plaintiffs, defendants, and support people were asked how personally affected the support people were by the situation ( $0=$ not personally affected; $1=$ less personally affected; $2=$ equally affected; $3=$ more affected) and how influential they were to the decision-making $(0=$ not very influential; $1=$ somewhat influential; $2=$ very influential $)$. ${ }^{4}$ Of the total number of surveys completed, 37 of these were excluded because they were completed by attorneys.
} 
Because some individuals declined to answer all questions, some variables reflect a different $\mathrm{N}$.

For binary variables (i.e. yes or no answers), we provide the percent of observations that fall in the particular category and the raw number that fall into that category in the Frequency (Freq.) column. For continuous or multi-level variables (e.g. scale of 1-5 or age), we provide the range, mean, and standard deviation.

Table 1. Descriptive and Summary Statistics for Each Variable

\begin{tabular}{|c|c|c|c|c|c|}
\hline Variable Name & $\mathrm{N}$ & Freq. & Percent & & Mean (SD) \\
\hline \multicolumn{6}{|c|}{ Pre-Intervention Measures } \\
\hline ADR & & 235 & $51 \%$ & & \\
\hline Jurisdiction Where Case Was Filed & 461 & & & & \\
\hline Baltimore City & & 263 & $57 \%$ & & \\
\hline Montgomery & & 198 & $43 \%$ & & \\
\hline Type of Case Filed & 461 & & & & \\
\hline Breach of Lease & & 23 & $05 \%$ & & \\
\hline Contract & & 318 & $69 \%$ & & \\
\hline Detinue & & 9 & $02 \%$ & & \\
\hline Forcible Entry and Detainer & & 23 & $05 \%$ & & \\
\hline Replevin & & 5 & $01 \%$ & & \\
\hline Tenant Holding Over & & 46 & $10 \%$ & & \\
\hline Tort & & 14 & $03 \%$ & & \\
\hline Wrongful Detainer & & 23 & $05 \%$ & & \\
\hline Role in Court Case & 418 & & & & \\
\hline Plaintiff & & 184 & $44 \%$ & & \\
\hline Defendant & & 184 & $44 \%$ & & \\
\hline Plaintiff Support & & 4 & $1 \%$ & & \\
\hline Defendant Support & & 13 & $3 \%$ & & \\
\hline Other & & 0 & $0 \%$ & & \\
\hline Plaintiff Attorney & & 23 & $5 \%$ & & \\
\hline Defendant Attorney & & 14 & $3 \%$ & & \\
\hline \multicolumn{6}{|l|}{ Representation } \\
\hline Represented & & 52 & $14 \%$ & & \\
\hline Consult Counsel & & 57 & $18 \%$ & & \\
\hline Support Present & & 92 & $27 \%$ & & \\
\hline \multicolumn{6}{|l|}{ Prior Experience and Case History } \\
\hline Prior Conversation & & 205 & $55 \%$ & & \\
\hline Pre-Responsibility Level & 378 & & & 0 to 2 & $.37(.61)$ \\
\hline Length of Conflict (in months) & 368 & & & 1 to 240 & $13.68(22.68)$ \\
\hline Police Involvement & & 64 & $17 \%$ & & \\
\hline Related Case & & 53 & $14 \%$ & & \\
\hline \multicolumn{6}{|c|}{ Level of Agreement (5) or Disagreement (1) with the following statements: } \\
\hline Feel Prepared & 398 & & & 1 to 5 & $4.05(.87)$ \\
\hline Clear Idea & 412 & & & 1 to 5 & $4.30(.80)$ \\
\hline
\end{tabular}




\begin{tabular}{|c|c|c|c|c|c|}
\hline Variable Name & $\mathrm{N}$ & Freq. & Percent & & Mean $(\mathrm{SD})$ \\
\hline Pre-Number of Ways to Resolve & 384 & & & 1 to 5 & $3.88(.99)$ \\
\hline Pre-My Needs Important & 386 & & & 1 to 5 & $4.37(.61)$ \\
\hline Pre-Important to Understand Other & 383 & & & 1 to 5 & $3.72(1.08)$ \\
\hline Pre-Learn They Are Wrong & 385 & & & 1 to 5 & $4.06(1.02)$ \\
\hline Pre-Their Needs Important & 382 & & & 1 to 5 & $3.20(1.17)$ \\
\hline Pre-Positive Relationship & 384 & & & 1 to 5 & $3.14(1.16)$ \\
\hline Pre-No Control & 383 & & & 1 to 5 & $3.16(1.24)$ \\
\hline Pre-Wants Opposite & 384 & & & 1 to 5 & $3.78(0.92)$ \\
\hline Pre-Can Talk about Concerns & 384 & & & 1 to 5 & $3.00(1.21)$ \\
\hline Pre-No Difference & 377 & & & 1 to 5 & $3.13(1.12)$ \\
\hline Pre-Conflict Negative & 381 & & & 1 to 5 & $3.73(1.06)$ \\
\hline Pre-Court Cares & 381 & & & 1 to 5 & $3.82(0.87)$ \\
\hline \multicolumn{6}{|c|}{ Demographics } \\
\hline Gender & 387 & & & & \\
\hline Male & & 190 & $49 \%$ & & \\
\hline Female & & 197 & $51 \%$ & & \\
\hline Age & 386 & & & 17 to 90 & $46.63(14.08)$ \\
\hline Below Poverty ${ }^{5}$ & & 76 & $24 \%$ & & \\
\hline Below $125 \%$ Poverty & & 98 & $31 \%$ & & \\
\hline Below 50\% MD & & 168 & $53 \%$ & & \\
\hline Below MD Med & & 242 & $76 \%$ & & \\
\hline Below $150 \%$ MD & & 286 & $85 \%$ & & \\
\hline Race & 384 & & & & \\
\hline White & & 115 & $30 \%$ & & \\
\hline Black & & 223 & $58 \%$ & & \\
\hline Hispanic & & 15 & $4 \%$ & & \\
\hline Asian & & 15 & $4 \%$ & & \\
\hline Other & & 15 & $4 \%$ & & \\
\hline Born in US & & 199 & $79 \%$ & & \\
\hline English Proficiency & 384 & & & 0 to 3 & $2.85(0.39)$ \\
\hline Military & & 36 & $9 \%$ & & \\
\hline Disability & & 61 & $16 \%$ & & \\
\hline Relationship to Other Party: & 379 & & & & \\
\hline Friends & & 23 & $6 \%$ & & \\
\hline Boy/Girl & & 4 & $1 \%$ & & \\
\hline Ex-Boy/Girl & & 8 & $2 \%$ & & \\
\hline Spouses & & 4 & $1 \%$ & & \\
\hline Divorced & & 4 & $1 \%$ & & \\
\hline Other Family & & 30 & $8 \%$ & & \\
\hline Employee & & 4 & $1 \%$ & & \\
\hline Former Employee & & 4 & $1 \%$ & & \\
\hline Co-workers & & 8 & $2 \%$ & & \\
\hline Neighbors & & 8 & $2 \%$ & & \\
\hline Roommates & & 4 & $1 \%$ & & \\
\hline Strangers & & 11 & $3 \%$ & & \\
\hline
\end{tabular}

${ }^{5}$ To create the income-based variables, we asked parties their household income and their household size and used that data to determine the appropriate household income classification. 


\begin{tabular}{|c|c|c|c|c|c|}
\hline Variable Name & $\mathrm{N}$ & Freq. & Percent & & Mean (SD) \\
\hline LLT & & 133 & $35 \%$ & & \\
\hline Business & & 106 & $28 \%$ & & \\
\hline \multicolumn{6}{|c|}{ Post-Intervention Measures } \\
\hline \multicolumn{6}{|c|}{ Level of Agreement (5) or Disagreement (1) with the following statements: } \\
\hline Post-I Could Express Myself & 345 & & & 1 to 5 & $4.13(0.88)$ \\
\hline Post-I Became Clearer & 360 & & & 1 to 5 & $3.82(0.92)$ \\
\hline Post-Other Better Understands Me & 343 & & & 1 to 5 & $3.1(1.12)$ \\
\hline Post-I Better Understand Other & 344 & & & 1 to 5 & $3.19(1.16)$ \\
\hline Post-Underlying Issues & 373 & & & 1 to 5 & $3.58(1.11)$ \\
\hline Post-Other Person Listened & 342 & & & 1 to 5 & $3.21(1.11)$ \\
\hline Post-Outcome is Fair & 362 & & & 1 to 5 & $3.67(1.21)$ \\
\hline Post-Can Implement Outcome & 328 & & & 1 to 5 & $3.86(0.89)$ \\
\hline Post-Satisfied with Judiciary & 361 & & & 1 to 5 & $1.7(0.66)$ \\
\hline Negotiated Agreement & 461 & & & 1 to 5 & $0.347(0.47)$ \\
\hline \multicolumn{6}{|l|}{ Resolution and Responsibility: } \\
\hline Post-Issues Resolved & 363 & & & 0 to 2 & $1.32(0.86)$ \\
\hline Post-Responsibility Level & 336 & & & 0 to 2 & $0.46(0.64)$ \\
\hline Post-I Took Responsibility & & 101 & $36 \%$ & & \\
\hline Post-I Apologized & & 71 & $21 \%$ & & \\
\hline Post-Other Took Responsibility & & 122 & $36 \%$ & & \\
\hline Post-Other Apologized & & 80 & $24 \%$ & & \\
\hline Post-No Apology or Responsibility & & 167 & $46 \%$ & & \\
\hline \multicolumn{6}{|c|}{$\begin{array}{l}\text { Difference in values from pre-intervention to post-intervention (Created by subtracting the answer } \\
\text { given before the intervention from the answer given after the intervention) }\end{array}$} \\
\hline Difference-Level of Responsibility & 319 & & & -2 to 2 & $0.09(0.51)$ \\
\hline Difference-Number of Ways & 329 & & & -4 to 3 & $-0.1(1.11)$ \\
\hline Difference-My Needs & 333 & & & -4 to 3 & $-0.19(0.71)$ \\
\hline $\begin{array}{l}\text { Difference-Important to Understand } \\
\text { Other }\end{array}$ & 329 & & & -4 to 3 & $-0.04(1.05)$ \\
\hline Difference-Learn They Are Wrong & 327 & & & -4 to 3 & $-0.21(0.96)$ \\
\hline Difference-Their Needs & 328 & & & -4 to 3 & $-0.17(1.04)$ \\
\hline Difference-Positive Relationship & 327 & & & -4 to 4 & $-0.15(1.34)$ \\
\hline Difference-No Control & 325 & & & -4 to 4 & $-0.17(1.39)$ \\
\hline Difference-Wants Opposite & 325 & & & -4 to 4 & $-0.14(1.38)$ \\
\hline Difference-Can Talk Concerns & 329 & & & -4 to 4 & $-0.14(1.27)$ \\
\hline Difference-No Difference & 322 & & & -4 to 3 & $-0.05(1.24)$ \\
\hline Difference-Conflict Negative & 322 & & & -4 to 4 & $-0.14(0.85)$ \\
\hline Difference-Court Cares & 321 & & & -4 to 3 & $-0.01(0.89)$ \\
\hline \multicolumn{6}{|l|}{ Agreement Outcome: } \\
\hline ADR - agreement & & 123 & $27 \%$ & & \\
\hline Control - agreement & & 37 & $8 \%$ & & \\
\hline \multicolumn{6}{|l|}{ Legal Filing: } \\
\hline Negotiated Agreement & & 160 & $35 \%$ & & \\
\hline
\end{tabular}




\section{Summary Attitudinal Variables}

To consider the attitudinal factors, we combined certain variables to measure broader concepts. This allowed for a more streamlined analysis and created continuous rather than step variables. For example, responses to the question, "It's important that I get my needs met in the issues that brought me to court today" (Pre-My Need Important) was combined with data for "The other person/people need to learn that they are wrong in the issues that brought me to court today" (Pre-Learn They Are Wrong). Although these variables measure slightly different ideas, the new combined variable, See it My Way, allows for the exploration of the cross section of parties' prioritizing their own needs and believing that the other party's perspective was wrong.

The combination of these variables was based on our assumption that they measured related concepts. We used two other statistical methods to check whether important information was lost in the combinations. First, we found that each set of combined variables had a statistically significant difference of means between the control and treatment group in the same direction. Second, we tested for correlations among the variables and found that all correlations (while relatively low) were statistically significant and positive, as reflected in Table 2 .

Table 2: Correlation Coefficients for Pre-service Attitudinal Questions

\begin{tabular}{|l|l|}
\hline Variable Combinations & Correlation Coefficient \\
\hline Pre-My Need Important with Pre-Learn They Are Wrong & $0.27^{* *}$ \\
\hline Pre-Number of Ways and Pre-Positive Relationship & $0.17^{* *}$ \\
\hline Pre-No Difference and Can't Talk & $.18^{* *}$ \\
\hline Pre-Wants Opposite and Pre-No Control & $0.17^{* *}$ \\
\hline Pre-Wants Opposite and Pre-No Difference & $0.16^{* *}$ \\
\hline Pre-No Difference and Pre-No Control & $0.19^{* *}$ \\
\hline
\end{tabular}

* Significant at $\mathrm{p}<.05 * *$ Significant at $\mathrm{p}<.01$

Given these correlations, we concluded it was acceptable to go forward with the combined variables, defined in Table 3. 
Table 3: Definitions for New Combined Variables

\begin{tabular}{|l|l|}
\hline New Variable & Definition \\
\hline \multicolumn{2}{|c|}{ Pre-Intervention Measures } \\
\hline \multicolumn{2}{|l|}{ Average of Level of Agreement (5) or Disagreement (1) with the following statements: } \\
\hline See it My Way & $\begin{array}{l}\text { AVERAGE of "It's important that I get my needs met" and "The other person needs to } \\
\text { learn that they are wrong" }\end{array}$ \\
\hline Hopeless & $\begin{array}{l}\text { AVERAGE of "I feel like I have no control over what happens", "The other person } \\
\text { wants the exact opposite of what I want," and "It doesn't seem to make any difference } \\
\text { what I do it will just remain the same." }\end{array}$ \\
\hline $\begin{array}{l}\text { Positive } \\
\text { Possibilities }\end{array}$ & $\begin{array}{l}\text { AVERAGE of "I think there are a number of different ways to resolve the issues" and } \\
\text { "It's important to me to have a positive relationship with the other person involved." }\end{array}$ \\
\hline Nothing Helps & $\begin{array}{l}\text { AVERAGE of "It doesn't make any difference what I do in regard to this situation, it } \\
\text { will just remain the same," and "I cannot talk about my concerns to the person } \\
\text { involved." (Created by switching the order of the answers to "I can talk about my } \\
\text { concerns to the other person involved") }\end{array}$ \\
\hline
\end{tabular}

Table 4 provides the descriptive and summary statistics for the new variables.

Table 4: Descriptive and Summary Statistics for New Variables

\begin{tabular}{|l|c|c|c|c|c|}
\hline New Variable & $\mathrm{N}$ & & & $\begin{array}{c}\text { Mean } \\
\text { (SD) }\end{array}$ \\
\hline \multicolumn{7}{|c|}{ Pre-Intervention Measures } \\
\hline Average of Level of Agreement (5) or Disagreement (1) with the following statements: \\
\hline See it My Way & 387 & & & 2 to 5 & $\begin{array}{c}4.21 \\
(0.66)\end{array}$ \\
\hline Hopeless & 387 & & & 1.33 to 5 & $\begin{array}{c}3.36 \\
(0.74)\end{array}$ \\
\hline Positive Possibilities & 387 & & & 1 to 5 & $\begin{array}{c}3.52 \\
(0.83)\end{array}$ \\
\hline Nothing Helps & 387 & & & 1 to 5 & $\begin{array}{c}3.07 \\
(0.91)\end{array}$ \\
\hline
\end{tabular}

Building the Model and Consideration of Possible Selection Bias

Because ADR is voluntary, we cannot know for sure whether those who ended up in the comparison group would have consented to ADR if offered the option. Therefore, we reviewed case characteristics, demographics, and pre-test attitudinal variables with a difference of means and chi-squared tests to identify variables that might be different between the comparison group and the treatment group, using a conservative cut-off of $\mathrm{p}<.05$ as a test for significance. We 
identified differences between the treatment and control groups, which we subsequently controlled for in the final model. These differences included:

Jurisdiction: Due to logistical factors and time limitations on the research, Montgomery County had slightly more ADR cases and Baltimore City had slightly more comparison cases. We negated possible jurisdictional differences by including a dummy variable for the jurisdiction.

Case Type: Contract cases were more likely to be found in the ADR group, with few breach of lease, replevin (return of property with possible damages), and tort cases relative to the overall case load. Contract cases were therefore controlled in the analysis.

Legal Representation: There was no significant difference between the control and treatment group in representation on the day of the trial. Individuals in the control group were more likely to have consulted counsel in advance of their trial date and were more likely to have a support person other than counsel present. Both of these are considered in the analysis below and controlled for in the various models.

Demographic Measures: Older people, white people, and those born in the United States were more likely to be in the treatment group. Individuals in households with incomes below the poverty line and below $125 \%$ of the poverty line were more likely to be in the comparison group. This proportion may result from the different demographics in Baltimore City and Montgomery County, because the latter had a greater number of ADR cases. Another explanation may be that individuals in the comparison group were offered a $\$ 10$ gift card for completing the interview on the day of trial, as well as the $\$ 10$ check for participating in the follow up phone interview three months later. We included a test for this explanation and any differences were mitigated by controlling for demographics throughout. 
Attitudinal Measures: Because a number of pre-test attitudinal measures provided conflicting results, ${ }^{6}$ we generated attitudinal values that could help explore further which of these affected the outcomes of interest and predicted participation in ADR in a logistic regression model.

Although no pattern raised a concern about selection bias, we further examined two equations with ADR as the dependent variable to explore if demographic differences might have an impact on the model's ability to predict ADR participation. This further informed the variables for which we controlled in the final model.

\section{Short-Term Results}

The tables below show the results of the analysis testing the impact of ADR on various attitudinal outcomes. For ordinal dependent, both ordinary least squares and ordered logistic regression models were used. When both show a statistically significant effect of ADR, it increases confidence in the conclusions. For all the variables reported, each demonstrated statistically significant results at a 95\% confidence level. Only the results for the ordered logistic regressions were included. For binary dependent variables (i.e. 0 or 1), only logistic regression was used. For ordinal dependent variables, the difference between which there cannot be an expectation of equality (e.g. yes, partial, no), we used ordinary least squares, ordered logistic regression, and multinomial logistic regression, and compared the outcomes for the three different tests for consistency.

In the equations below, pre-test attitudinal measures were significantly different between ADR and comparison groups for the following: See it My Way, Clear Idea, and Positive Possibilities. The model therefore includes these variables.

\footnotetext{
${ }^{6}$ For example, the control group was more likely to agree that they were hopeless about the situation, but also more likely to agree that there were a number of ways to resolve the case (expressing an optimistic sense of possibility).
} 
To measure the intensity and escalation of the conflict, the variable Police Called was included. In addition, the Length of Conflict was included to consider whether the matter was ripe for settlement. While opinions differ about when ADR is most appropriately timed, most scholars agree that timing matters in some way (Clarke \& Gordon, 1997; McAdoo, Welsh \& Wissler, 2003 p. 9; Wissler, 2002). We also controlled for whether the participants were represented by or consulted an attorney prior to the trial date, as this may influence how they perceive their ADR or trial experience.

The analysis includes a variable for whether the parties had a related case in court on the theory that individuals may be less likely to acknowledge responsibility or apologize for the situation if they are worried that their statements might be used against them in another context. We also included a variable measuring the level of responsibility reported by the party prior to the trial or mediation (e.g., "I took responsibility," "No one took responsibility"). Controlling for these variables allows us to identify any shifts in the level of responsibility reported by the party from before to after the trial or mediation. Consult Counsel (which indicates a party consulted with a lawyer prior to the trial date) was found to have a negative and significant effect on Underlying Issues. Therefore, we included Consult Counsel in the model measuring the impact of ADR on Underlying Issues and in the model for Issues Resolved as these two outcomes may be related.

Table 5 measures the effect of ADR on Negotiated Agreement, comparing those who reached agreement on their own prior to trial (without any ADR) and those who reached agreement in the ADR session. After that, Negotiated Agreement is included in the equations as a control variable. Some participants in the comparison group settled on their own before their case was called and entered their resolution in the court records as a negotiated agreement. All 
agreements reached in mediation were likewise recorded as negotiated agreement. This allowed us to test whether ADR itself supported any positive outcomes, or if the parties would have experienced the same positive outcomes if they reached agreement on their own, without ADR. Controlling for Negotiated Agreement in all of these equations allowed us to isolate the impact of participating in ADR itself, separate from its value of increasing the likelihood that participants will settle. In other words, we measure the benefits of ADR regardless of whether the parties settle in ADR.

Table 5: $\quad$ Logistic Regressions Results: ADR on Negotiated Agreement

\begin{tabular}{|l|c|}
\hline Variable & $\begin{array}{c}\text { Negotiated } \\
\text { Agreement }\end{array}$ \\
\hline ADR & $\begin{array}{c}1.85^{* *} \\
(5.05)\end{array}$ \\
\hline Baltimore City & $\begin{array}{c}-0.07 \\
(-0.19)\end{array}$ \\
\hline Plaintiff & $\begin{array}{c}-0.09 \\
(-0.23)\end{array}$ \\
\hline Represented & $\begin{array}{c}-0.22 \\
(-0.23)\end{array}$ \\
\hline Length of Conflict & $\begin{array}{c}0.10 \\
(1.58)\end{array}$ \\
\hline Police Called & $\begin{array}{l}-0.83 \\
(-1.66)\end{array}$ \\
\hline Consult Counsel & $\begin{array}{c}-0.15 \\
(-0.34)\end{array}$ \\
\hline See It My Way & $\begin{array}{c}-0.11 \\
(-0.43)\end{array}$ \\
\hline Positive Possibilities & $\begin{array}{c}-0.25 \\
(-1.13)\end{array}$ \\
\hline Hopeless & $\begin{array}{c}-0.46 \\
(-1.66)\end{array}$ \\
\hline Nothing Helps & $\begin{array}{c}-0.18 \\
(-0.82)\end{array}$ \\
\hline Clear idea & $\begin{array}{c}-0.21 \\
(-1.00)\end{array}$ \\
\hline Male & $\begin{array}{l}0.18 \\
(0.56)\end{array}$ \\
\hline Below Poverty & $\begin{array}{l}0.09 \\
(0.23)\end{array}$ \\
\hline White & $\begin{array}{l}-0.49 \\
(-1.15)\end{array}$ \\
\hline
\end{tabular}




\begin{tabular}{|l|c|}
\hline Variable & $\begin{array}{c}\text { Negotiated } \\
\text { Agreement }\end{array}$ \\
\hline Born in the US & -0.17 \\
& $(-0.38)$ \\
\hline Military Veteran & -0.73 \\
& $(-1.30)$ \\
\hline Constant & 2.67 \\
& $(1.47)$ \\
\hline Number of Observations & 249 \\
\hline Pseudo R-squared & 0.2054 \\
\hline
\end{tabular}

* Significant at $\mathrm{p}<.05 * *$ Significant at $\mathrm{p}<.01$

Reaching Agreement. ADR has a positive and significant effect on the probability of reaching a negotiated agreement. The other demographic variables and attitudinal measures are not significant in this measure. This equation cannot be used to predict the effect of ADR on a negotiated settlement directly, because this is a participant database, not a case database. Cases with multiple participants would be overrepresented in such an analysis. In essence, this equation indicates that participants who participate in ADR are more likely to reach a negotiated settlement than those who proceed to trial without ADR, even holding constant for all of the demographic and other factors.

Table 6 summarizes the results of logistic regression to examine the impact of ADR on several post-test measures. We then measured the predicted probability based on the outcomes of the regression analysis to quantify the impact of ADR. The predicted probability provided the probability of getting a certain answer if someone goes through ADR compared to the standard court process, holding constant for all other factors in the equation. 
Table 6: Order Logistic Regression Results: ADR on I Could Express Myself, Underlying Issues, Issues Resolved, Difference in Responsibility, and Difference in Learn They Are Wrong

\begin{tabular}{|c|c|c|c|c|c|}
\hline Variable & $\begin{array}{c}\text { I Could } \\
\text { Express } \\
\text { Myself }\end{array}$ & $\begin{array}{c}\text { Underlying } \\
\text { Issues }\end{array}$ & $\begin{array}{c}\text { Issues } \\
\text { Resolved }\end{array}$ & $\begin{array}{c}\text { Difference- } \\
\text { Level } \\
\text { Responsibility }\end{array}$ & $\begin{array}{c}\text { Difference } \\
\text { - Learn } \\
\text { They Are } \\
\text { Wrong }\end{array}$ \\
\hline $\mathrm{ADR}$ & $\begin{array}{l}.70^{*} \\
(2.30)\end{array}$ & $\begin{array}{c}.63^{*} \\
(1.99)\end{array}$ & $\begin{array}{c}.80^{*} \\
(2.39)\end{array}$ & $\begin{array}{c}.90^{*} \\
(2.22)\end{array}$ & $\begin{array}{l}-.69 * \\
(-2.30)\end{array}$ \\
\hline Baltimore City & $\begin{array}{c}-.08 \\
(-0.24) \\
\end{array}$ & $\begin{array}{c}.04 \\
(0.10) \\
\end{array}$ & $\begin{array}{c}-.30 \\
(-0.08) \\
\end{array}$ & $\begin{array}{c}-.37 \\
(-0.86) \\
\end{array}$ & $\begin{array}{c}-.21 \\
(-0.67) \\
\end{array}$ \\
\hline Contract & $\begin{array}{c}-.02 \\
(-0.07) \\
\end{array}$ & $\begin{array}{c}.76 \\
(2.17) \\
\end{array}$ & $\begin{array}{c}.33 \\
(0.93) \\
\end{array}$ & $\begin{array}{c}-.19 \\
(-0.44) \\
\end{array}$ & $\begin{array}{c}-.25 \\
(-0.78) \\
\end{array}$ \\
\hline Consult Counsel & & $\begin{array}{l}-.79^{*} \\
(-2.29)\end{array}$ & $\begin{array}{c}-.12 \\
(-0.31)\end{array}$ & $\begin{array}{c}.81 \\
(1.87)\end{array}$ & \\
\hline Plaintiff & $\begin{array}{l}.62^{*} \\
(2.01)\end{array}$ & $\begin{array}{c}.29 \\
(0.94)\end{array}$ & $\begin{array}{c}.34 \\
(1.00)\end{array}$ & $\begin{array}{c}.48 \\
(1.23)\end{array}$ & $\begin{array}{c}-.55 \\
(-1.93)\end{array}$ \\
\hline Represented & $\begin{array}{c}.46 \\
(0.99)\end{array}$ & $\begin{array}{c}-.72 \\
(-0.71)\end{array}$ & $\begin{array}{c}.17 \\
(0.11)\end{array}$ & $\begin{array}{c}-.18 \\
(-0.14)\end{array}$ & $\begin{array}{c}.20 \\
(0.45)\end{array}$ \\
\hline $\begin{array}{l}\text { Pre-Level of } \\
\text { Responsibility }\end{array}$ & $\begin{array}{c}.28 \\
(1.20) \\
\end{array}$ & & & & \\
\hline Positive Possibilities & $\begin{array}{c}.12 \\
(0.68)\end{array}$ & $\begin{array}{c}.17 \\
(0.92)\end{array}$ & $\begin{array}{c}.11 \\
(0.57)\end{array}$ & $\begin{array}{c}.02 \\
(0.09)\end{array}$ & $\begin{array}{c}.24 \\
(1.46)\end{array}$ \\
\hline Clear Idea & $\begin{array}{c}.02 \\
(0.11)\end{array}$ & $\begin{array}{c}-.07 \\
(-0.37)\end{array}$ & $\begin{array}{c}-.11 \\
(-0.52)\end{array}$ & $\begin{array}{c}.11 \\
(0.47)\end{array}$ & $\begin{array}{c}-14 \\
(-0.79)\end{array}$ \\
\hline Length of Conflict & $\begin{array}{c}.01 \\
(1.61)\end{array}$ & $\begin{array}{l}.01^{*} \\
(2.50)\end{array}$ & $\begin{array}{c}.00 \\
(0.88)\end{array}$ & $\begin{array}{c}.01 \\
(1.27)\end{array}$ & $\begin{array}{c}.00 \\
(1.06)\end{array}$ \\
\hline Police Called & $\begin{array}{c}.09 \\
(0.25)\end{array}$ & $\begin{array}{c}-.54 \\
(-1.40)\end{array}$ & $\begin{array}{c}-.20 \\
(-0.49)\end{array}$ & $\begin{array}{c}.46 \\
(1.00)\end{array}$ & $\begin{array}{c}-.38 \\
(-1.10)\end{array}$ \\
\hline See It My Way & $\begin{array}{c}.28 \\
(1.21) \\
\end{array}$ & $\begin{array}{c}.34 \\
(1.50) \\
\end{array}$ & $\begin{array}{c}-.37 \\
(-1.38) \\
\end{array}$ & $\begin{array}{c}-.09 \\
(-0.32) \\
\end{array}$ & \\
\hline Pre-My Needs Important & & & & & $\begin{array}{l}-.61 * * \\
(-2.59)\end{array}$ \\
\hline Male & $\begin{array}{c}.17 \\
(0.64)\end{array}$ & $\begin{array}{c}-.17 \\
(-0.62)\end{array}$ & $\begin{array}{c}-.37 \\
(-1.24)\end{array}$ & $\begin{array}{c}.78 \\
(2.19 *)\end{array}$ & $\begin{array}{c}-.48 \\
(-1.84)\end{array}$ \\
\hline Below Poverty & $\begin{array}{c}-.11 \\
(-0.33) \\
\end{array}$ & $\begin{array}{c}.15 \\
(0.43)\end{array}$ & $\begin{array}{c}-.51 \\
(-1.42)\end{array}$ & $\begin{array}{c}-.27 \\
(-0.64)\end{array}$ & $\begin{array}{c}-.25 \\
(-0.75)\end{array}$ \\
\hline White & $\begin{array}{c}-.09 \\
(-0.29) \\
\end{array}$ & $\begin{array}{c}.44 \\
(1.26) \\
\end{array}$ & $\begin{array}{c}.66 \\
(1.74) \\
\end{array}$ & $\begin{array}{c}-0.03 \\
(-0.07)\end{array}$ & $\begin{array}{c}-.43 \\
(-1.36) \\
\end{array}$ \\
\hline Age & $\begin{array}{c}-.01 \\
(-1.39)\end{array}$ & $\begin{array}{l}-.006 \\
(-0.65)\end{array}$ & $\begin{array}{c}-.00 \\
(-0.23) \\
\end{array}$ & $\begin{array}{c}.01 \\
(0.82)\end{array}$ & $\begin{array}{c}.00 \\
(0.45)\end{array}$ \\
\hline Negotiated Agreement & $\begin{array}{c}.13 \\
(0.44) \\
\end{array}$ & $\begin{array}{c}.82^{*} \\
(2.49)\end{array}$ & $\begin{array}{l}1.33 * * \\
(3.48)\end{array}$ & $\begin{array}{c}-.26 \\
(-0.65)\end{array}$ & $\begin{array}{c}-.53 \\
(-1.71)\end{array}$ \\
\hline Number of Observations & 242 & 222 & 216 & 216 & 242 \\
\hline Pseudo R-squared & 0.0405 & 0.0817 & 0.1321 & 0.0726 & 0.0560 \\
\hline
\end{tabular}

$*$ Significant at $\mathrm{p}<.05 * *$ Significant at $\mathrm{p}<.01$ 
Expression. ADR has a positive and significant effect on participants reporting "I was able to express myself, my thoughts, and my concerns." Plaintiff also has a positive and significant effect on I Could Express Myself. ADR has a positive and significant effect on participants reporting that "all of the underlying issues in this conflict came out." Participants in longer conflicts were more likely to report that the underlying issues came out. Participants who reached a negotiated agreement were more likely to report that all of the underlying issues came out.

Resolution of Issues. ADR has a positive and significant effect on Post-Issues Resolve, with ADR participants more likely to report the issues were resolved. Participants who reached a negotiated agreement were also more likely to report that the issues were resolved. Because it cannot be assumed that the difference between 0 (not resolved) and 1 (partially resolved) is the same as the difference between 1 (partially resolved) and 2 (fully resolved), we conducted a check of the ordered least squares and ordered logistic regression results with multinomial logistic regression. This step allowed the assumptions to be relaxed. Multinomial logistic regression measures the effect of the impact of the variables on each of the outcomes, compared to one fixed outcome. In this case, it measured the effect of ADR on a 0 compared to the result of ADR on 2 and the effect of ADR on 1 compared to the effect of ADR on 2.

The results of the multinomial logistic regression indicates that the negative and significant coefficient on ADR in (Issues Resolved =1) means that ADR participants are less likely to report partial resolution compared to their likelihood of reporting full resolution. The negative and significant coefficient on Negotiated Agreement in (Issues Resolved $=0$ ) means that participants who got a negotiated agreement are less likely to report no resolution compared to their likelihood of reporting full resolution. 
Graph 1: Predicted probability of "Issues Resolved," holding constant for all other factors

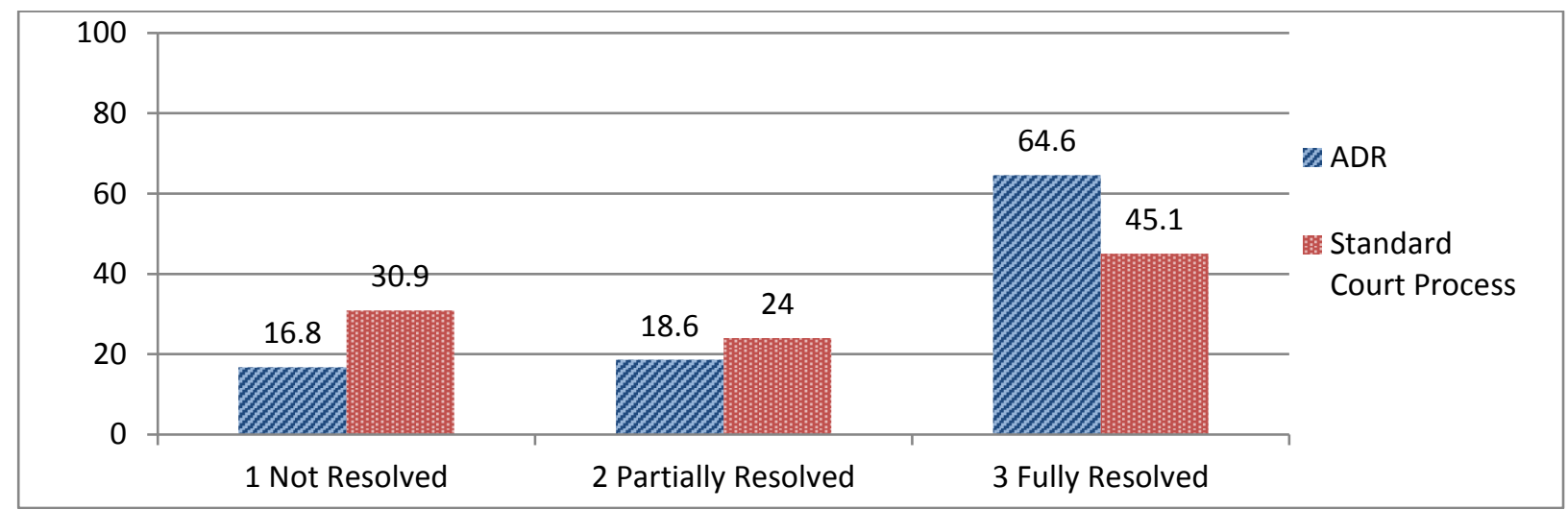

Responsibility. ADR has a positive and significant effect on Difference-Level of

Responsibility, with ADR participants reporting a higher level of responsibility after the intervention than before. Men are also more likely than women to report a higher level of responsibility after the intervention than before in both court and ADR.

Participants in ADR were more likely to shift toward disagreement with the statement "the other person needs to learn they are wrong" from before to after the process. Participants who were more likely to report that it's important to get their needs met in the pre-test were more likely to shift toward disagreement with the statement "the other person needs to learn they are wrong" from before to after the process.

Table 7 summarizes an examination of the effects of ADR on two additional post-test measures using logistic regression. 
Table 7: Logistic Regression Results: ADR on "I Took Responsibility" and "No One Took Responsibility or Apologized"

\begin{tabular}{|c|c|c|}
\hline Variable & $\begin{array}{c}\text { I Took } \\
\text { Responsibility }\end{array}$ & $\begin{array}{c}\text { No One Took } \\
\text { Responsibility or } \\
\text { Apologized }\end{array}$ \\
\hline ADR & $\begin{array}{c}1.47 * * \\
(2.90)\end{array}$ & $\begin{array}{l}-0.79^{*} \\
(-2.26)\end{array}$ \\
\hline Baltimore City & $\begin{array}{c}-0.22 \\
(-0.44)\end{array}$ & $\begin{array}{c}-.026 \\
(-0.73)\end{array}$ \\
\hline Represented & $\begin{array}{c}-0.63 \\
(-0.70)\end{array}$ & $\begin{array}{c}0.27 \\
(0.48)\end{array}$ \\
\hline Plaintiff & $\begin{array}{c}-0.22 \\
(-0.45)\end{array}$ & $\begin{array}{c}-0.23 \\
(-0.66) \\
\end{array}$ \\
\hline Length of Conflict & $\begin{array}{c}0.00 \\
(0.05)\end{array}$ & $\begin{array}{c}-0.01 \\
(-1.04) \\
\end{array}$ \\
\hline Police Called & $\begin{array}{c}-0.64 \\
(-0.86)\end{array}$ & $\begin{array}{c}-0.02 \\
(-0.05)\end{array}$ \\
\hline Pre-Level of Responsibility & $\begin{array}{l}1.09 * * \\
(3.08)\end{array}$ & $\begin{array}{l}-0.67 * \\
(-2.49)\end{array}$ \\
\hline Related Case & $\begin{array}{c}-0.71 \\
(-0.93) \\
\end{array}$ & $\begin{array}{c}1.05 \\
(1.83)\end{array}$ \\
\hline See it My Way & $\begin{array}{c}-0.56 \\
(-1.62)\end{array}$ & $\begin{array}{c}0.44 \\
(1.72)\end{array}$ \\
\hline Positive Possibilities & $\begin{array}{c}0.40 \\
(1.25)\end{array}$ & $\begin{array}{c}-0.01 \\
(-0.04)\end{array}$ \\
\hline Male & $\begin{array}{l}1.04^{*} \\
(2.37)\end{array}$ & $\begin{array}{c}-0.36 \\
(-1.16)\end{array}$ \\
\hline Below Poverty & $\begin{array}{c}0.23 \\
(0.44) \\
\end{array}$ & $\begin{array}{l}0.90^{*} \\
(2.21)\end{array}$ \\
\hline White & $\begin{array}{c}-1.08 \\
(-1.73) \\
\end{array}$ & $\begin{array}{c}0.55 \\
(1.38)\end{array}$ \\
\hline Negotiated Agreement & $\begin{array}{c}0.79 \\
(1.68)\end{array}$ & $\begin{array}{l}-0.120 \\
(-0.34) \\
\end{array}$ \\
\hline Constant & $\begin{array}{c}-2.54 \\
(-1.31) \\
\end{array}$ & $\begin{array}{c}-0.25 \\
(-0.18) \\
\end{array}$ \\
\hline Number of Observations & 240 & 238 \\
\hline Pseudo R-squared & 0.3011 & 0.1240 \\
\hline
\end{tabular}

$*$ Significant at $\mathrm{p}<.05 * *$ Significant at $\mathrm{p}<.01$

ADR has a positive and significant effect on participants reporting that they acknowledged responsibility. Participants who reported higher levels of responsibility in the pretest were also more likely to report in the post-test that they took responsibility. Men were more likely to report that they took responsibility. 
ADR participants were less likely to report that no one took responsibility or apologized. Participants who reported higher levels of responsibility in the pre-test were less likely to report in the post-test that no one took responsibility. Participants in households with incomes below poverty were more likely to report that no one took responsibility.

Satisfaction with the Judiciary. The next set of equations test the effect of attending ADR and reaching a negotiated agreement (with or without the aid of ADR) on Satisfaction with the Judiciary. Table 8 summarizes the results.

Table 8: Ordered Logistic Regression Results: ADR on "Satisfied with Judiciary" and Agreement in ADR on "Satisfied with Judiciary"

\begin{tabular}{|c|c|c|}
\hline Variable & $\begin{array}{l}\text { ADR on Satisfied } \\
\text { w/ Judiciary }\end{array}$ & $\begin{array}{l}\text { ADR Agreement } \\
\text { and Comparison } \\
\text { Agreement on } \\
\text { Satisfied w/ } \\
\text { Judiciary }\end{array}$ \\
\hline ADR & $\begin{array}{c}0.43 \\
(0.85)\end{array}$ & \\
\hline Attend ADR-agreement & & $\begin{array}{c}2.75^{* * *} \\
(2.61)\end{array}$ \\
\hline Control -agreement & & $\begin{array}{c}1.58 \\
(1.41) \\
\end{array}$ \\
\hline Hopeless & $\begin{array}{c}-0.25 \\
(-0.79)\end{array}$ & $\begin{array}{c}-0.28 \\
(-0.90)\end{array}$ \\
\hline Related Case & $\begin{array}{c}-0.04 \\
(-0.07)\end{array}$ & $\begin{array}{c}0.07 \\
(0.12)\end{array}$ \\
\hline Consult Counsel & $\begin{array}{c}-0.48 \\
(-0.99) \\
\end{array}$ & $\begin{array}{c}-0.49 \\
(-1.01) \\
\end{array}$ \\
\hline Plaintiff & $\begin{array}{c}0.56 \\
(1.18)\end{array}$ & $\begin{array}{c}0.49 \\
(1.05)\end{array}$ \\
\hline Represented & $\begin{array}{l}-2.54^{*} \\
(-2.16)\end{array}$ & $\begin{array}{l}-2.37^{*} \\
(-2.08)\end{array}$ \\
\hline Length of Conflict & $\begin{array}{c}0.01 \\
(0.58)\end{array}$ & $\begin{array}{c}0.01 \\
(0.71)\end{array}$ \\
\hline Police Called & $\begin{array}{c}-0.42 \\
(-0.88) \\
\end{array}$ & $\begin{array}{c}-0.41 \\
(-0.86) \\
\end{array}$ \\
\hline Clear Idea & $\begin{array}{c}-0.15 \\
(-0.56)\end{array}$ & $\begin{array}{c}-0.20 \\
(-0.74)\end{array}$ \\
\hline Male & $\begin{array}{c}-0.15 \\
(-0.35)\end{array}$ & $\begin{array}{c}-0.17 \\
(-0.40)\end{array}$ \\
\hline Below Poverty & $\begin{array}{c}0.26 \\
(0.54)\end{array}$ & $\begin{array}{c}0.23 \\
(0.48)\end{array}$ \\
\hline
\end{tabular}




\begin{tabular}{|l|c|c|}
\hline Variable & $\begin{array}{c}\text { ADR on Satisfied } \\
\text { w/ Judiciary }\end{array}$ & $\begin{array}{c}\text { ADR Agreement } \\
\text { and Comparison } \\
\text { Agreement on } \\
\text { Satisfied w/ } \\
\text { Judiciary }\end{array}$ \\
\hline White & 0.06 & 0.11 \\
$(0.10)$ & $0.05^{* *}$ \\
\hline Age & $0.05^{* *}$ & $(3.08)$ \\
\hline Negotiated Agreement & $(2.95)$ & \\
Reached & $2.17^{* *}$ & 216 \\
\hline Number of Observations & $(2.75)$ & 0.1749 \\
\hline Pseudo R-squared & 216 & .01756 \\
\hline
\end{tabular}

* Significant at $\mathrm{p}<.05 * *$ Significant at $\mathrm{p}<.01$

The first column in Table 8 indicates that ADR does not have a significant effect on Satisfied with the Judiciary, but Negotiated Agreement has a positive and significant effect. To test whether a negotiated agreement in ADR has a different effect from a "hallway" negotiated agreement before trial without any ADR, the two types of negotiated agreements were separated in an additional analysis indicated in the second column. Age also has a positive and significant effect on Satisfied with Judiciary and Represented has a negative and significant effect on Satisfied with Judiciary.

The second column shows that reaching an agreement in ADR has a positive and significant effect on Satisfied with Judiciary, while reaching an agreement on one's own (i.e., without any participation in ADR) does not. Age has a positive and significant effect on Satisfied with the Judiciary and Represented has a negative and significant effect on Satisfied with Judiciary.

\section{LONG-TERM IMPACT OF ADR}

\section{Data Set}

Table 9 shows the summary statistics for participant level data used in the short- and long-term analysis, as well as summary statistics for variables used only in the long-term 
analysis. For case-level variables, most summary statistics in the long-term analysis are the same as in the short-term. Participant-level variables may be different because of the cases lost when participants could not be reached for a follow-up telephone interview.

Table 9: $\quad$ Summary Statistics for Long-Term Analysis

\begin{tabular}{|c|c|c|c|c|c|}
\hline Variable Name & $\mathrm{N}$ & Freq. & Percent & Range & Mean (SD) \\
\hline \multicolumn{6}{|c|}{ Participant Level Data } \\
\hline ADR Case & 166 & 102 & 61.45 & & \\
\hline Comparison, negotiated agreement & 166 & 6 & 3.61 & & \\
\hline ADR, agreement & 166 & 55 & 33.13 & & \\
\hline Contract & 166 & 107 & 64.46 & & \\
\hline Plaintiff & 161 & 83 & 51.55 & & \\
\hline Represented & 154 & 15 & 9.74 & & \\
\hline Related Case & 155 & 21 & 13.55 & & \\
\hline Below $125 \%$ Poverty & 136 & 50 & 30.88 & & \\
\hline Days Between Court and Follow-up & 166 & & & 65 to 343 & $\begin{array}{r}133.88 \\
(53.67) \\
\end{array}$ \\
\hline Police Called & 157 & 29 & 18.47 & & \\
\hline Length of Conflict & 157 & & & 1 to 240 & $13.79(26.68)$ \\
\hline Feel Prepared & 187 & & & 1 to 5 & $4.08(.580)$ \\
\hline Baltimore City & 166 & 110 & 66.27 & & \\
\hline Prior Conversation & 157 & 98 & 62.42 & & \\
\hline Male & 161 & 78 & 48.45 & & \\
\hline Diff- Number of Ways & 166 & & & -5 to 5 & $.35(1.52)$ \\
\hline Diff- My Needs & 166 & & & -5 to 5 & $.05(1.36)$ \\
\hline Diff- Imp. to Understand Other & 166 & & & -5 to 5 & $.18(1.59)$ \\
\hline Diff- Learn They Are Wrong & 166 & & & -5 to 5 & $-.07(1.48)$ \\
\hline Diff- Their Needs & 166 & & & -5 to 4 & $.24(1.47)$ \\
\hline Diff- Positive Relationship & 166 & & & -5 to 4 & $-.13(1.43)$ \\
\hline Diff- No Control & 166 & & & -5 to 4 & $.10(1.55)$ \\
\hline Diff- Wants Opposite & 166 & & & -4 to 4 & $.02(1.35)$ \\
\hline Diff- Can Talk Concerns & 166 & & & -5 to 4 & $-.13(1.62)$ \\
\hline Diff- No Difference & 166 & & & -5 to 4 & $.11(1.50)$ \\
\hline Diff- Conflict Negative & 166 & & & -5 to 5 & $.03(1.55)$ \\
\hline Diff- Court Cares & 166 & & & -5 to 5 & $-.10(1.50)$ \\
\hline Issues Resolved - L- to after diff & 163 & & & 1 to 5 & $3.23(1.30)$ \\
\hline Satisfied Judiciary $-\mathrm{L}$ & 163 & & & 1 to 5 & $3.63(1.13)$ \\
\hline Satisfied Outcome - L & 164 & & & 1 to 5 & $3.43(1.45)$ \\
\hline Outcome Workable - L & 161 & & & 1 to 5 & $3.30(1.49)$ \\
\hline I Followed Through - L & 160 & & & 1 to 5 & $4.66(.93)$ \\
\hline Other Person Followed Through - L & 154 & & & 1 to 5 & $3.66(1.71)$ \\
\hline New Problems Arose - L & 162 & 20 & 12.35 & & \\
\hline \multicolumn{6}{|c|}{ Case Level Data } \\
\hline Return to Court & 183 & 69 & 37.7 & & \\
\hline Pre Number of Ways & 166 & & & -5 to 5 & $.35(1.53)$ \\
\hline
\end{tabular}




\begin{tabular}{|l|c|c|c|c|c|}
\hline Variable Name & $\mathrm{N}$ & Freq. & Percent & Range & Mean (SD) \\
\hline Pre My Needs & 166 & & & -5 to 5 & $.05(1.36)$ \\
\hline Pre Important I Understand & 166 & & & -5 to 5 & $.18(1.59)$ \\
\hline Pre Clear Idea & 166 & & & -5 to 5 & $-.06(1.48)$ \\
\hline Pre Their Needs & 166 & & & -5 to 4 & $.24(1.47)$ \\
\hline Pre Positive Relationship & 166 & & & -5 to 4 & $-.13(1.43)$ \\
\hline Pre No Control & 166 & & & -5 to 4 & $.10(1.55)$ \\
\hline Pre Wants Opposite & 166 & & & -4 to 4 & $.02(1.35)$ \\
\hline Pre Can Talk & 166 & & & -5 to 4 & $-.13(1.62)$ \\
\hline No Difference & 166 & & & -5 to 4 & $.11(1.50)$ \\
\hline Feel Prepared & 159 & & & 1 to 5 & $4.14(.786)$ \\
\hline ADR, agreement & 189 & 49 & 25.9 & & \\
\hline Comparison, negotiated agreement & 189 & 15 & 7.9 & & \\
\hline Contract & 189 & 127 & 67.2 & & \\
\hline Anyone Called Police & 189 & 45 & 23.8 & & \\
\hline Represented & 189 & 23 & 12.2 & & \\
\hline Prior Conversation & 187 & 105 & 56.2 & & \\
\hline Age & 188 & & & 17 to 78 & $46.45(11.19)$ \\
\hline Below 125\% Poverty & 177 & 53 & 30.0 & & \\
\hline Related Case & 187 & 28 & 15.0 & & \\
\hline Length of Conflict & 185 & & & 1 to 180 & $14.09(19.13)$ \\
\hline Personal Relationship & 186 & 47 & 25.3 & & \\
\hline
\end{tabular}

\section{Creating New Combined Variables}

We used principal component analysis to create new variables that combine the variables measuring similar concepts. The minimum Eigen value was set at 1, and varimax was used for the factor matrix rotation. We reviewed the outputs with the settings to report loadings greater than .3 and determined to be either consistent with theory or at least not totally inconsistent with theory or conventional wisdom. New variables were created using the factor loadings associated with each of the variables. We used loadings greater than .3 to create a more comprehensive understanding of the newly created variables.

Table 10 defines the variables measuring the pre-intervention attitude. These variables are case level variables, created by averaging the responses of the participants in any given case. 
Table 10: PCA Case Level Participant Pre-Attitudinal Measures

\begin{tabular}{|c|c|c|c|}
\hline $\begin{array}{l}\text { Participant-Pre } \\
\text { Good Relationship } \\
\text { - Case }\end{array}$ & $\begin{array}{l}\text { Participant- Pre Our } \\
\text { Needs - Case }\end{array}$ & $\begin{array}{l}\text { Participant - Pre } \\
\text { Hopeless - Case }\end{array}$ & $\begin{array}{l}\text { Participant - Pre } \\
\text { Court Cares - Case }\end{array}$ \\
\hline $\begin{array}{l}\text { The other } \\
\text { person/people need/s } \\
\text { to learn that they are } \\
\text { wrong in the issues } \\
\text { that brought me to } \\
\text { court today. }(-0.43)\end{array}$ & $\begin{array}{l}\text { I think there are a } \\
\text { number of different ways } \\
\text { to resolve the issues that } \\
\text { brought me to court } \\
\text { today. }(+0.56)\end{array}$ & $\begin{array}{l}\text { It's important that I get } \\
\text { my needs met in the } \\
\text { issues that brought me to } \\
\text { court today. }(+0.31)\end{array}$ & $\begin{array}{l}\text { I feel like I have no } \\
\text { control over what } \\
\text { happens in the issues } \\
\text { that brought me to } \\
\text { court today. }(+0.36)\end{array}$ \\
\hline $\begin{array}{l}\text { It's important that } \\
\text { the other } \\
\text { person/people get } \\
\text { their needs met in } \\
\text { the issues that } \\
\text { brought me to court } \\
\text { today. }(+0.37)\end{array}$ & $\begin{array}{l}\text { It's important that I get } \\
\text { my needs met in the } \\
\text { issues that brought me to } \\
\text { court today. }(+0.35)\end{array}$ & $\begin{array}{l}\text { It's important for me to } \\
\text { have a positive } \\
\text { relationship with the } \\
\text { other person/people } \\
\text { involved in the issues } \\
\text { that brought me to court } \\
\text { today. }(+0.30)\end{array}$ & $\begin{array}{l}\text { The court system } \\
\text { cares about helping } \\
\text { people resolve } \\
\text { disputes in a fair } \\
\text { manner. }(+0.79)\end{array}$ \\
\hline $\begin{array}{l}\text { It's important for me } \\
\text { to have a positive } \\
\text { relationship with the } \\
\text { other person/people } \\
\text { involved in the } \\
\text { issues that brought } \\
\text { me to court today. } \\
(+0.50)\end{array}$ & $\begin{array}{l}\text { It's important that I } \\
\text { understand what the } \\
\text { other person/people } \\
\text { want/s in the issues that } \\
\text { brought me to court } \\
\text { today. }(+0.57)\end{array}$ & $\begin{array}{l}\text { I feel like I have no } \\
\text { control over what } \\
\text { happens in the issues that } \\
\text { brought me to court } \\
\text { today. }(+0.35)\end{array}$ & \\
\hline $\begin{array}{l}\text { The other } \\
\text { person/people } \\
\text { involved in the } \\
\text { issues that brought } \\
\text { me to court today } \\
\text { want/s the exact } \\
\text { opposite of what I } \\
\text { want. (-0.46) }\end{array}$ & $\begin{array}{l}\text { It's important that the } \\
\text { other person/people get } \\
\text { their needs met in the } \\
\text { issues that brought me to } \\
\text { court today. }(+0.34)\end{array}$ & $\begin{array}{l}\text { It doesn't seem to make } \\
\text { any difference what I do } \\
\text { in regard to the issues } \\
\text { that brought me to court } \\
\text { today, it'll just remain } \\
\text { the same. } \\
(+0.60)\end{array}$ & \\
\hline $\begin{array}{l}\text { I can talk about my } \\
\text { concerns to the } \\
\text { person/people } \\
\text { involved in the } \\
\text { issues that brought } \\
\text { me to court today. } \\
(+0.38)\end{array}$ & & $\begin{array}{l}\text { In general, conflict is a } \\
\text { negative thing. }(+0.47)\end{array}$ & \\
\hline
\end{tabular}

Table 11 shows the combination of the variables that measure the difference in attitude from before the court or ADR intervention and at the time of the follow up interview (3-6 months later). PCA combines these variables into two new variables. 
Table 11: PCA Participant Level Differences in Attitude from Before Intervention to Follow-up Survey

\begin{tabular}{|l|l|}
\hline \multicolumn{1}{|c|}{ Improved Relationship - Participant } & \multicolumn{1}{|c|}{ More Hopeless - Participant } \\
\hline $\begin{array}{l}\text { I think there are a number of different ways } \\
\text { to resolve the issues that brought me to court } \\
\text { today. }(+0.42)\end{array}$ & $\begin{array}{l}\text { The other person/people need/s to learn that they are } \\
\text { wrong in the issues that brought me to court today. } \\
(+0.42)\end{array}$ \\
\hline $\begin{array}{l}\text { It's important that I get my needs met in the } \\
\text { issues that brought me to court today. } \\
(+0.30)\end{array}$ & $\begin{array}{l}\text { I feel like I have no control over what happens in } \\
\text { the issues that brought me to court today. }(+0.50)\end{array}$ \\
\hline $\begin{array}{l}\text { It's important that I understand what the } \\
\text { other person/people want/s in the issues that } \\
\text { brought me to court today. }(+0.42)\end{array}$ & $\begin{array}{l}\text { The other person/people involved in the issues that } \\
\text { brought me to court today want/s the exact opposite } \\
\text { of what I want. }(+0.49)\end{array}$ \\
\hline $\begin{array}{l}\text { It's important that the other person/people } \\
\text { get their needs met in the issues that brought } \\
\text { me to court today. }(+0.42)\end{array}$ & $\begin{array}{l}\text { It doesn't seem to make any difference what I do in } \\
\text { regard to the issues that brought me to court today, } \\
\text { it'll just remain the same. }(+0.43)\end{array}$ \\
\hline $\begin{array}{l}\text { It's important for me to have a positive } \\
\text { relationship with the other person/people } \\
\text { involved in the issues that brought me to } \\
\text { court today. }(+0.37)\end{array}$ & \\
\hline $\begin{array}{l}\text { I can talk about my concerns to the } \\
\text { person/people involved in the issues that } \\
\text { brought me to court today. }(+0.33)\end{array}$ & \\
\hline
\end{tabular}


Table 12 shows the combination of variables from the follow up survey regarding how well the outcome is working. PCA combines the variables into two new variables.

Table 12: PCA Participant Follow Up Report

\begin{tabular}{|l|l|}
\hline \multicolumn{1}{|c|}{ Things Working - Participant } & \multicolumn{1}{c|}{ Things Not Working - Participant } \\
\hline $\begin{array}{l}\text { I feel like the issues that brought us to court } \\
\text { three months ago are fully resolved. }(+0.38)\end{array}$ & $\begin{array}{l}\text { How well did the others follow through on the } \\
\text { agreement or judicial decision? (-0.47) }\end{array}$ \\
\hline $\begin{array}{l}\text { I am satisfied with my interaction with the } \\
\text { judicial system in this case. (+0.49) }\end{array}$ & $\begin{array}{l}\text { Have new problems with the other person in this } \\
\text { case (which you did not discuss at the time) } \\
\text { arisen in the last three months? (+0.82) }\end{array}$ \\
\hline $\begin{array}{l}\text { Three months after your ADR session or } \\
\text { trial, how satisfied are you with the outcome } \\
\text { from trial? (+0.50) }\end{array}$ & \\
\hline $\begin{array}{l}\text { How well is the outcome you reached in the } \\
\text { ADR session or trial working for you? } \\
(+0.48)\end{array}$ & \\
\hline
\end{tabular}

\section{Regression Model}

This portion of the study sought to understand the impact of ADR on a range of longterm outcomes, including whether the parties returned to court for enforcement action and parties' attitudes toward the opposing side, the situation that had brought them to court, and their experience with the judicial system. In order to isolate the impact of ADR, we used ordinary least squares multiple regression analysis, logistic regression analysis, and ordered logistic regression. We controlled for other factors that could affect a litigant's experience and choices by including measures such as: the length of the conflict, whether parties were represented by or consulted counsel, whether the police had been called in the past for matters related to the case (as a measure of conflict escalation), participants' attitude, the type of case, whether the parties had a personal relationship, and party demographics (such as age, gender, race). Finally, we held constant the number of months between the original court date and time of the interview. These variables allowed us to consider that as parties adjust to the outcome of ADR or trial, their perspective about the situation may change. We used the same methods to ensure rigor in the 
analysis as described previously, including tests for multicollinearity and removal of any variable with substantial missing data.

In analyzing whether participants returned to court for an enforcement action, three factors were of interest: the impact of reaching an agreement in ADR, the impact of getting an agreement on their own without any ADR, and the impact of receiving a judge verdict. All three could not be included in the same equation because the variable for getting an agreement in mediation was correlated with the variable of receiving a verdict at -0.65 , well above our cut-off of 0.5 . Therefore, the same equation was analyzed with similar variables twice, once with Agreement in ADR and Comparison Agreement, and a second time with Verdict.

\section{Results}

Table 13 shows the results of the Ordinary Least Squares Regression testing the impact of participating in ADR in parties' changes in attitude from before the intervention to the follow up interview and on the parties' report of how well the outcome is working.

Table 13: Impact of ADR on Changes in Participant Attitude and Report on Outcome using Ordinary Least Squares

\begin{tabular}{|l|c|c|c|c|}
\hline Variable & $\begin{array}{c}\text { Improved } \\
\text { Relationship }\end{array}$ & $\begin{array}{c}\text { More } \\
\text { Hopeless }\end{array}$ & $\begin{array}{c}\text { Things } \\
\text { Working }\end{array}$ & $\begin{array}{c}\text { Things Not } \\
\text { Working }\end{array}$ \\
\hline \multirow{2}{*}{ ADR Case } & $0.77^{*}$ & -0.03 & $0.75^{*}$ & -0.05 \\
& $(2.16)$ & $(-0.10)$ & $(2.07)$ & $(-0.19)$ \\
\hline \multirow{2}{*}{ Contract } & 0.49 & -0.07 & -0.02 & -0.22 \\
& $(1.29)$ & $(-0.26)$ & $(-0.06)$ & $(-0.76)$ \\
\hline \multirow{2}{*}{ Plaintiff } & 0.25 & 0.45 & 0.05 & 0.24 \\
& $(0.76)$ & $(1.83)$ & $(0.14)$ & $(0.95)$ \\
\hline \multirow{2}{*}{ Represented or Consulted Attorney } & 0.67 & 0.31 & 0.07 & $0-.01$ \\
& $(1.18)$ & $(0.74)$ & $(0.11)$ & $(-0.01)$ \\
\hline \multirow{2}{*}{ Related Case } & -0.64 & 0.29 & -0.88 & 0.34 \\
& $(-1.14)$ & $(0.71)$ & $(-1.56)$ & $(0.82)$ \\
\hline \multirow{2}{*}{ Below 125\% Poverty } & -0.60 & 0.18 & $-0.85^{*}$ & -0.38 \\
& $(-1.51)$ & $(0.62)$ & $(-2.11)$ & $(-1.28)$ \\
\hline \multirow{2}{*}{ Personal Relationship } & 0.10 & -0.07 & 0.30 & -0.34 \\
& $(-0.22)$ & $(-0.23)$ & $(0.68)$ & $(-1.07)$ \\
\hline
\end{tabular}




\begin{tabular}{|l|c|c|c|c|}
\hline Variable & $\begin{array}{c}\text { Improved } \\
\text { Relationship }\end{array}$ & $\begin{array}{c}\text { More } \\
\text { Hopeless }\end{array}$ & $\begin{array}{c}\text { Things } \\
\text { Working }\end{array}$ & $\begin{array}{c}\text { Things Not } \\
\text { Working }\end{array}$ \\
\hline Days Between Court and Follow-up & -0.00 & 0.00 & -0.00 & -0.00 \\
survey & $(-.32)$ & $(0.34)$ & $(-0.40)$ & $(-1.10)$ \\
\hline Police Called & 0.58 & 0.00 & $-1.28^{* *}$ & 0.26 \\
& $(1.41)$ & $(0.01)$ & $(-3.12)$ & $(0.87)$ \\
\hline Length of Conflict & -0.01 & $-0.01^{*}$ & -0.01 & 0.01 \\
& $(-1.60)$ & $(-2.25)$ & $(-1.31)$ & $(1.43)$ \\
\hline \multirow{2}{*}{ Baltimore City } & 0.59 & -0.07 & $0.83^{*}$ & 0.29 \\
& $(1.44)$ & $(-0.25)$ & $(2.01)$ & $(0.97)$ \\
Prior Conversation & $0-.62$ & -0.04 & $-0.77^{*}$ & 0.09 \\
& $(-1.83)$ & $(-0.15)$ & $(-2.27)$ & $(0.38)$ \\
\hline \multirow{2}{*}{ Male } & -0.11 & 0.15 & -0.11 & -0.32 \\
& $(-0.33)$ & $(0.62)$ & $(-0.33)$ & $(-1.29)$ \\
\hline Feel prepared & 0.09 & $-0.36 *$ & 0.23 & -0.09 \\
& $(0.45)$ & $(-2.45)$ & $(1.15)$ & $(-0.60)$ \\
\hline Constant & -1.15 & 1.15 & -0.64 & 0.64 \\
& $(-1.01)$ & $(1.37)$ & $(-0.57)$ & $(0.79)$ \\
\hline Number & 121 & 121 & 111 & 111 \\
\hline Adjusted R-Squared & 0.0727 & 0.0208 & 0.2052 & 0.0220 \\
\hline
\end{tabular}

Participation in ADR resulted in an increase in parties' report on indicators measuring the quality of the relationship from before the intervention to several months later. Participation in ADR did not have a significant impact on an increase in a sense of hopelessness. However, the length of the conflict prior to the intervention and the parties' sense of preparation prior to the intervention had a negative effect on this variable.

Participation in ADR resulted in positive reports from litigants that the outcome was working and that they were satisfied with the judicial system several months after the intervention. Parties' income level being below $125 \%$ of poverty; the police having been called before the intervention; and having had a prior conversation with the other party before the court date all had a negative effect on parties' reports that the outcome was working and that they were satisfied with the outcome and judicial system several months after the intervention. 
None of the variables examined had a statistically significant impact on parties' report that things were not working or new problems had arisen since the intervention.

In Table 14, the same equations were run, replacing participation in ADR with agreement in ADR to determine if reaching an agreement in ADR had any different effects on the long-term reports from participants.

Table 14: Impact of ADR Agreement on Changes in Participant Attitude and Report on Outcome using Ordinary Least Squares

\begin{tabular}{|c|c|c|c|c|}
\hline & $\begin{array}{c}\text { Improved } \\
\text { Relationship }\end{array}$ & $\begin{array}{c}\text { More } \\
\text { Hopeless }\end{array}$ & $\begin{array}{c}\text { Things } \\
\text { Working }\end{array}$ & $\begin{array}{l}\text { Things Not } \\
\text { Working }\end{array}$ \\
\hline Agreement in ADR & $\begin{array}{c}0.08 \\
(0.22)\end{array}$ & $\begin{array}{l}-0.23 \\
(-0.91)\end{array}$ & $\begin{array}{l}0.86^{*} \\
(2.39)\end{array}$ & $\begin{array}{l}-0.08 \\
(-0.29)\end{array}$ \\
\hline Contract & $\begin{array}{c}0.49 \\
(1.24)\end{array}$ & $\begin{array}{c}-0.03 \\
(-0.12)\end{array}$ & $\begin{array}{l}-0.23 \\
(-0.56)\end{array}$ & $\begin{array}{l}-0.20 \\
(-0.67)\end{array}$ \\
\hline Plaintiff & $\begin{array}{c}0.26 \\
(0.75)\end{array}$ & $\begin{array}{c}0.47 \\
(1.95)\end{array}$ & $\begin{array}{l}-0.08 \\
(-0.23)\end{array}$ & $\begin{array}{c}0.25 \\
(0.98)\end{array}$ \\
\hline Represented or Consulted Attorney & $\begin{array}{c}0.77 \\
(1.32)\end{array}$ & $\begin{array}{c}0.36 \\
(0.86)\end{array}$ & $\begin{array}{c}0.06 \\
(0.10)\end{array}$ & $\begin{array}{l}-0.00 \\
(-0.00)\end{array}$ \\
\hline Related Case & $\begin{array}{l}-0.48 \\
(-0.85)\end{array}$ & $\begin{array}{c}0.29 \\
(0.71) \\
\end{array}$ & $\begin{array}{l}-0.70 \\
(-1.26)\end{array}$ & $\begin{array}{c}0.33 \\
(0.81) \\
\end{array}$ \\
\hline Below $125 \%$ Poverty & $\begin{array}{l}-0.69 \\
(-1.70)\end{array}$ & $\begin{array}{c}0.19 \\
(0.65)\end{array}$ & $\begin{array}{l}-0.98^{*} \\
(-2.43)\end{array}$ & $\begin{array}{l}-0.37 \\
(-1.25)\end{array}$ \\
\hline Personal Relationship & $\begin{array}{c}0.12 \\
(0.27)\end{array}$ & $\begin{array}{c}-0.06 \\
(-0.18)\end{array}$ & $\begin{array}{c}0.48 \\
(1.13)\end{array}$ & $\begin{array}{l}-0.35 \\
(-1.14)\end{array}$ \\
\hline $\begin{array}{l}\text { Days Between Court and Follow- } \\
\text { up Survey }\end{array}$ & $\begin{array}{c}-0.00 \\
(-0.58)\end{array}$ & $\begin{array}{c}0.00 \\
(0.39)\end{array}$ & $\begin{array}{c}-0.00 \\
(-0.66)\end{array}$ & $\begin{array}{l}-0.00 \\
(-1.09)\end{array}$ \\
\hline Police Called & $\begin{array}{c}46 \\
(1.12)\end{array}$ & $\begin{array}{c}-0.02 \\
(-0.07)\end{array}$ & $\begin{array}{l}-1.28 \\
(-3.16)\end{array}$ & $\begin{array}{c}0.26 \\
(0.87)\end{array}$ \\
\hline Length of Conflict & $\begin{array}{c}-0.01 \\
(-1.71)\end{array}$ & $\begin{array}{c}-0.01 \\
(-2.30) \\
\end{array}$ & $\begin{array}{c}-0.01 \\
(-1.29)\end{array}$ & $\begin{array}{c}0.01 \\
(1.43)\end{array}$ \\
\hline Baltimore City & $\begin{array}{c}0.34 \\
(0.86)\end{array}$ & $\begin{array}{c}-0.08 \\
(-0.29)\end{array}$ & $\begin{array}{c}0.62 \\
(1.58)\end{array}$ & $\begin{array}{c}0.30 \\
(1.06)\end{array}$ \\
\hline Prior Conversation & $\begin{array}{c}-0.48 \\
(-1.41)\end{array}$ & $\begin{array}{c}-0.02 \\
(-0.06)\end{array}$ & $\begin{array}{l}-0.69^{*} \\
(-2.09)\end{array}$ & $\begin{array}{c}0.09 \\
(0.37)\end{array}$ \\
\hline Male & $\begin{array}{c}-0.09 \\
(-0.26)\end{array}$ & $\begin{array}{c}0.16 \\
(0.68)\end{array}$ & $\begin{array}{c}-0.17 \\
(-0.51)\end{array}$ & $\begin{array}{c}-0.31 \\
(-1.26)\end{array}$ \\
\hline Feel prepared & $\begin{array}{c}0.02 \\
(0.11)\end{array}$ & $\begin{array}{c}-0.38 * * \\
(-2.60)\end{array}$ & $\begin{array}{c}0.25 \\
(1.25)\end{array}$ & $\begin{array}{c}-0.09 \\
(-0.62)\end{array}$ \\
\hline Constant & $\begin{array}{c}-0.25 \\
(-0.23)\end{array}$ & $\begin{array}{c}1.22 \\
(1.57)\end{array}$ & $\begin{array}{c}-0.13 \\
(-0.13)\end{array}$ & $\begin{array}{c}0.62 \\
(0.81)\end{array}$ \\
\hline Number & 121 & 121 & 111 & 111 \\
\hline Adjusted R-squared & 0.0325 & 0.0282 & 0.2160 & 0.0225 \\
\hline
\end{tabular}


Reaching an agreement in ADR has a statistically significant and positive effect on litigants' reporting that the outcome was working and that they were satisfied with the outcome and the judicial system several months after the intervention. It does not have a significant effect on other variables examined in Table 15.

Table 15 provides the results of case level analysis of the impact of an agreement in ADR, an agreement parties reached on their own, and a verdict on the likelihood of returning to court for an enforcement action in the 12 months following the intervention.

Table 15: Impact of ADR Agreement and Verdict on Cases Returning to Court for Enforcement Action within a Year

\begin{tabular}{|c|c|c|}
\hline & Return 1 Year & Return 1 Year \\
\hline Agreement in Mediation & $\begin{array}{l}-0.97 * \\
(-2.12) \\
\end{array}$ & \\
\hline Comparison Negotiated Agreement & $\begin{array}{c}-0.21 \\
(-0.28)\end{array}$ & \\
\hline Verdict & & $\begin{array}{l}0.83^{*} \\
(2.18)\end{array}$ \\
\hline Contract & $\begin{array}{c}0.15 \\
(0.31) \\
\end{array}$ & $\begin{array}{c}0.15 \\
(0.33) \\
\end{array}$ \\
\hline Anyone Call Police & $\begin{array}{c}-0.01 \\
(-0.03)\end{array}$ & $\begin{array}{c}-0.05 \\
(-0.10)\end{array}$ \\
\hline Attorney Present & $\begin{array}{c}0.56 \\
(0.93) \\
\end{array}$ & $\begin{array}{c}0.49 \\
(0.81) \\
\end{array}$ \\
\hline Prior Conversation & $\begin{array}{c}-0.06 \\
(-0.13)\end{array}$ & $\begin{array}{c}-0.10 \\
(-0.20)\end{array}$ \\
\hline Feel Prepared & $\begin{array}{c}0.02 \\
(0.07)\end{array}$ & $\begin{array}{c}0.08 \\
(0.25)\end{array}$ \\
\hline Age & $\begin{array}{c}-0.01 \\
(-0.40)\end{array}$ & $\begin{array}{c}-0.01 \\
(-0.52)\end{array}$ \\
\hline Bellow $125 \%$ Poverty line & $\begin{array}{c}0.36 \\
(0.71) \\
\end{array}$ & $\begin{array}{c}0.40 \\
(0.78)\end{array}$ \\
\hline Related Case & $\begin{array}{c}0.11 \\
(0.17)\end{array}$ & $\begin{array}{c}0.07 \\
(0.12)\end{array}$ \\
\hline Length of Conflict & $\begin{array}{l}0.03^{*} \\
(2.29)\end{array}$ & $\begin{array}{l}0.04^{*} \\
(2.68)\end{array}$ \\
\hline Personal Relationship & $\begin{array}{c}-0.81 \\
(-1.75)\end{array}$ & $\begin{array}{c}-0.78 \\
(-1.67)\end{array}$ \\
\hline Participant - Pre Good Relationship & $\begin{array}{c}-0.13 \\
(-0.96)\end{array}$ & $\begin{array}{c}-0.13 \\
(-1.01)\end{array}$ \\
\hline
\end{tabular}




\begin{tabular}{|l|c|c|}
\hline Participant - Pre Our Needs & $\begin{array}{c}-0.00 \\
(-0.01)\end{array}$ & $\begin{array}{c}-0.00 \\
(-0.01)\end{array}$ \\
\hline \multirow{2}{*}{ Participant - Pre Hopeless } & 0.02 & 0.03 \\
& $(0.09)$ & $(0.21)$ \\
\hline \multirow{2}{*}{ Participant - Pre Court Cares } & -0.18 & -0.21 \\
& $(-1.03)$ & $(-1.24)$ \\
\hline \multirow{2}{*}{ Constant } & -0.61 & -1.54 \\
& $(-0.35)$ & $(-0.88)$ \\
\hline Number & 165 & 165 \\
\hline Pseudo R-squared & 0.1080 & 0.1083 \\
\hline
\end{tabular}

Reaching an agreement in ADR has a negative and statistically significant impact on returning to court for an enforcement action. Comparison cases in which parties reached a negotiated agreement on their own were neither more or less likely to return to court for an enforcement action; and cases with a verdict were more likely to return to court for an enforcement action. The length of the conflict prior to the intervention was also positively associated with the likelihood of returning to court for an enforcement action.

Graph 2 and 3 show the predicted probabilities of returning to court for an enforcement action. Graph 2 shows the predicted probability of a case returning to court within one year, based on whether or not they reached an agreement in ADR compared to cases that did participate in ADR, settled outside of ADR, or participated in ADR without an agreement. These findings hold constant all other factors in the estimated equation. 
Graph 2: Predicted Probability of Cases Returning to Court for an Enforcement Action within One Year, holding constant for all other factors: Agreement in ADR vs. All Other Cases

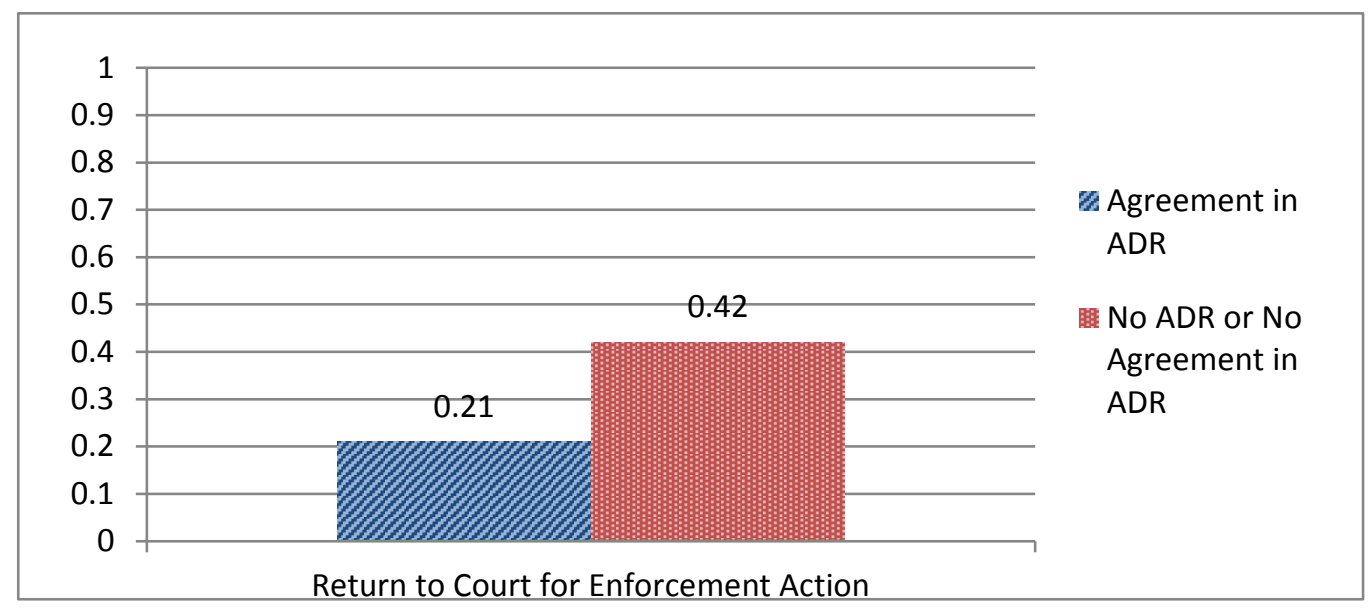

Graph 3 shows the predicated probability that a case that received a verdict will return to court within one year, as compared to all other cases, holding constant all other factors in the equation.

Graph 3: Predicted Probability of Cases Returning to Court for an Enforcement Action within One Year, holding constant for all other factors: Verdict vs. All Other Case Outcomes

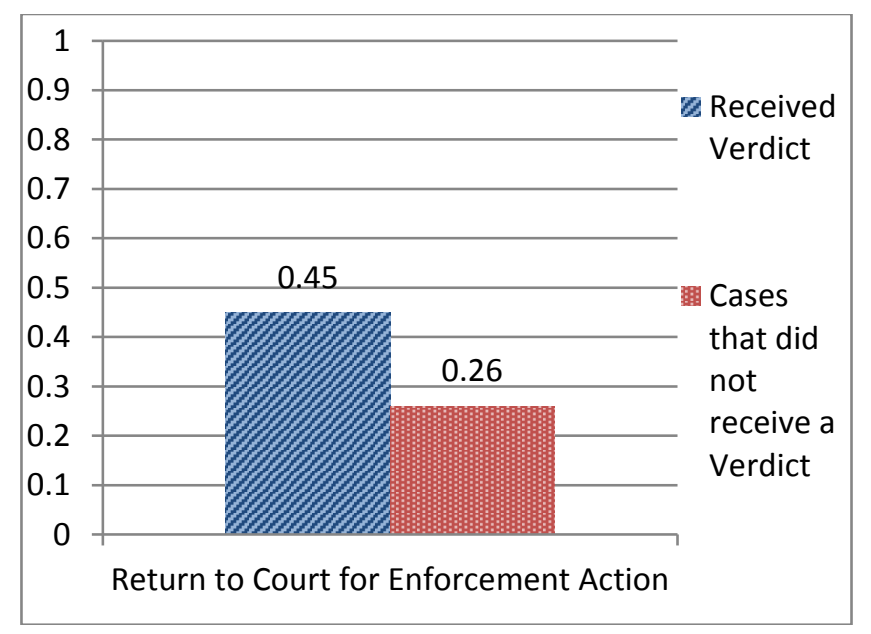

Reaching an agreement in ADR decreases the predicted probability of returning to court for an enforcement action by $21 \%$, compared to all other cases (i.e., those that reached a verdict, did not settle in ADR, and comparison cases in which parties reached an agreement on their own 
without any ADR). Analysis of whether cases that did not reach agreement in ADR were more or less likely than control cases without agreement to return to court was inconclusive. There was some indication that comparison cases without agreements were more likely to return to court than ADR cases without agreements; however, the results were not sufficiently consistent and significant to report. This may be due in part to the small sample size. Future research should explore this issue further.

\section{Discussion}

ADR has significant positive, immediate impacts on parties who participated in ADR as compared to those who went to trial without ADR. In the short-term, ADR improves the parties' attitudes toward each other, gives parties a greater sense of empowerment and voice in the process, increases their taking of responsibility for the dispute, and increases their satisfaction with the judicial system more generally. In the long-term, ADR participants were more likely than the trial group to report an improved relationship with and attitude toward the other party, satisfaction with the outcome, and satisfaction with the judicial system. In addition, cases that settled in ADR were less likely to return to court for an enforcement action within the next year.

\section{A. Short-term Impact}

ADR participants were more likely than those who proceeded through the standard court process to indicate that: 1) they could express themselves, their thoughts, and their concerns; 2) all of the underlying issues came out; 3) the issues were resolved; 4) the issues were completely resolved rather than partially resolved; and 5) they acknowledged responsibility for the situation. Importantly, this was true for all ADR cases, including those that reached an agreement in ADR and those that did not settle. 
ADR permits participants to discuss topics beyond the legal issues in the case. This study confirms the value of these discussions in ADR, even if the parties do not settle the legal case. As compared to those who proceeded to trial without ADR, participation in ADR shifted party attitudes about their own level of responsibility for the conflict. Specifically, ADR participants had an increase in their rating of their level of responsibility for the situation from before to after the intervention. ADR also increased their appreciation for the opposing party's perspective, with ADR participants more likely to disagree with the statement "the other people [in the conflict] need to learn they are wrong" from before to after the process. ADR participants were also less likely to report that no one took responsibility or apologized than litigants who went through the standard court process without ADR. This finding confirms that ADR helps parties gain a new perspective on the conflict that adversarial litigation cannot offer.

Again, all of these short-term findings applied uniformly to ADR, regardless of whether the parties settled in ADR. Including a variable for negotiated agreement held constant for the settlement impact of ADR and included the potential benefits of the negotiated "hallway" agreements for those in the trial group who did not use ADR. Parties who reached agreement in ADR were more likely to be satisfied with the judicial system than all others. Those parties in the trial group who negotiated an agreement on their own without any ADR were not more likely to be satisfied with the judicial system than those who did not settle at all. This suggests that it is the process of reaching an agreement though the ADR process - rather than simply the fact of settlement - that causes higher satisfaction levels.

This research suggests that there are important short-term benefits of ADR for the parties beyond efficiency and settlement concerns. The ability to talk directly to the other side may explain many of the short-term findings. ADR allows the parties to express their thoughts and 
concerns more fully and discuss and potentially resolve all of the underlying issues. Judges must decide cases based only on the applicable law, and can award only the legal remedies available.

If they reach agreement in ADR, participants are more satisfied with the judiciary overall than those who go to trial without ADR. This is consistent with prior research that ADR offers a sense of voice and procedural justice that increases public confidence in the judicial system more generally.

Most of the dependent variables on which ADR did not have a significant impact are those that measure the difference in attitudes from immediately before to after the intervention. The average length of an ADR session in this study was 56 minutes, with five minutes being the minimum and 155 minutes the maximum. While the differences between these interventions clearly impacted several of the post-treatment measures, it is not surprising that there are not significant differences in some short-term attitudinal measures.

\section{B. Differences in Outcomes for Different Demographic Groups}

We also explored whether ADR had a different impact on the outcomes of interest for different demographic groups. Generally, we found no differences in the experience in ADR for the demographic groups tested here, with a few exceptions.

First, plaintiffs were more likely to report expressing themselves in court than nonplaintiffs and somewhat more likely to report expressing themselves in court than in ADR. As the party who brought the claim, plaintiffs in small claims matters typically seek monetary damages and presumably have come to court prepared to make their arguments to the judge about their entitlement to those damages or other relief. Being diverted to an ADR process on the day-of-trial, even though voluntarily accepted, may interfere with those expectations, whereas arguing to the judge in a trial may match their pre-trial expectations. 
Second and conversely, non-plaintiffs were more likely to report expressing themselves in ADR than plaintiffs. This also makes sense given the dynamics of most small claims cases. Non-plaintiffs here mean defendants, many of whom may be defending against a claim for monetary damages, as well as the nineteen support people who accompanied the parties ( 5 for plaintiffs, and 14 for defendants). ADR permits defendants to develop creative agreements, such as payment plans, that courts cannot award. To the extent this represents the responses of support people, ADR provides a forum in which they can join the discussion in a way that a trial does not permit.

Third, several findings stood out for litigants represented by counsel. Represented parties were more likely than non-represented parties to indicate they expressed themselves in court, less likely than non-represented parties to report that they expressed themselves in ADR, and more likely to report that they expressed themselves in court than in ADR. As with the finding regarding plaintiffs, this result could be explained by the pre-trial expectations of the parties. Represented parties may have discussed what would happen at trial with their counsel. If they go to trial and are able to express themselves as they had prepared, their pre-trial expectations are met. If they instead participate in an ADR session, their expectations about arguing their position in an adversarial trial have been altered. Alternatively, this finding may suggest, as some commentators have observed, that lawyers may dominate or not allow their clients to speak freely in ADR, perhaps decreasing the party's sense of voice in the process (Welsh, 2001). At the same time, represented parties were also more likely to apologize, suggesting that lawyers may play a valuable role in helping litigants to understand how they may be responsible for the dispute. 
Finally, age did not affect how parties who went to trial reported on whether issues were resolved or not; however, older individuals were more likely to report that issues were resolved in ADR than were younger individuals.

\section{Long-Term Impact of $A D R$}

Several striking long-term benefits of ADR emerged. Regardless of settlement, ADR participants were more likely than the trial group to report an improved relationship with and attitude toward the other party measured from before the intervention to three to six months later. This finding confirms that ADR can have important long-term relational benefits.

ADR participants are also more likely than trial participants to report that the outcome was working and that they were satisfied with the outcome and the judicial system three to six months after the intervention. This was true for all ADR participants, although it was slightly stronger for those who settled in ADR. This is important for the broader public respect for the judiciary and rule of law. As Wissler writes, "Litigants' experiences in court, particularly their judgments of procedural fairness, have been found to affect their general views of the legal system and its legitimacy" (1995, p. 352; see also, Tyler 2006).

Finally, the long-term analysis found that parties who settled in ADR were less likely to return to court for an enforcement action in the twelve months following the intervention compared to all other cases, including those that reached an agreement on their own, ADR cases that did settle, and cases with a judge verdict. Specifically, reaching an agreement in ADR decreased the predicted probability of returning to court by $21 \%$.

This finding suggests that courts should consider the durability of the ultimate resolution as well as immediate judicial efficiency and time savings. Although not all parties will settle in ADR, this study shows that parties who do are significantly less likely to consume court 
resources in the future as compared to cases with a judge verdict, and cases with a negotiated "hallway" agreement developed with no ADR.

\section{Limitations}

The primary limitation of this study is the relatively small sample size. ${ }^{7}$ In several equations where ADR was not found to be statistically significant, it appeared to be close to a reportable level of significance. A larger sample size might permit conclusions about additional impacts of ADR and potential differences in outcomes for various subgroups. Despite these limitations, this research provides one of the most rigorous studies to date of the impact of ADR as compared to trial. The results confirm many benefits of small claims ADR programs for litigants and the judiciary.

\section{Conclusion}

Participation in ADR causes significant positive outcomes in the short- and long-term. As compared to those who went through the standard court process, ADR participants are more likely to fully and completely resolve the issues in their conflict. Even if parties do not reach agreement in ADR, participation in ADR causes immediate and positive shifts in party attitudes toward each other. ADR participants are more likely to acknowledge personal responsibility for the conflict and to experience a positive shift in their attitude toward the opposing party. Three to six months later, ADR participants are more likely than those who proceed to trial without ADR to report an improved relationship with and attitude toward the other party. ADR participants are also more likely to report that the final outcome was working, that they are satisfied with the

\footnotetext{
${ }^{7}$ One of the reasons for the small data set is that this particular study was part of a larger study that also involved mediation observations and behavioral coding of the ADR session to examine the impact of specific mediator interventions. Conducting observations meant that the researchers could only do surveys for one ADR case at a time. A future study could be done on a larger scale if researchers collected only survey data.
} 
outcome, and that they are satisfied with the judiciary. ADR is also connected to a decrease in the repeat use of court resources in the long term, with ADR cases half as likely to return to court for further action as compared to trial cases that received a judge verdict.

This research confirms the many benefits of ADR as compared to trial, including relational shifts for the parties and long-term resource savings and increased public confidence for the courts. Importantly, this study isolates the value of simply participating in an ADR process, regardless of whether the parties reach agreement. Courts should continue to invest in ADR programs, and understand that the positive impacts of ADR extend far beyond settlement. 


\section{AUTHOR BIOGRAPHIES}

Lorig Charkoudian, Ph.D., is the Executive Director of Community Mediation Maryland. Her research examines the impact of specific aspects of the mediation process on experiences for participants as well as broader cost-benefit analysis of mediation for public entities.

Deborah Thompson Eisenberg, J.D., is Professor of Law and Faculty Director of the Center for Dispute Resolution at the University of Maryland Francis King Carey School of Law. She studies and teaches in the areas of dispute resolution and employment law.

Jamie L. Walter, Ph.D., is Director of Court Operations, Administrative Office of the Courts for the Maryland Judiciary. She has managed and conducted evaluations of a variety of court practices including those of mental health courts, teen courts, self-help centers, juvenile case management, and alternative dispute resolution.

\section{REFERENCES}

Anderson, H., and R. Pi. 2004. Evaluation of the Early Mediation Pilot Programs. Judicial Council of California: Administrative Office of the Courts.

Bundagg, J., and R. Flagg. 2003. Multi-Option ADR Project Evaluation Report, July 2001-July 2002, Superior Court of California, County of San Mateo.

Charkoudian, L. 2005. “A Quantitative Analysis of the Effectiveness of Community Mediation in Decreasing Repeat Police Calls for Service.” Conflict Resolution Quarterly 23 (1): 87-98. Charkoudian, L. 2010. “Giving Police and Courts a Break: The Effect of Community Mediation on Decreasing the Use of Police and Court Resources." Conflict Resolution Quarterly 28 (2): $141-55$. 
Charkoudian, L., Eisenberg, D, and Walter, J. 2017 (forthcoming). What Works in Small Claims $A D R$.

Clarke, S. H., E. D. Ellen, and K. McCormick. 1995. Court-Ordered Civil Case Mediation in North Carolina: An Evaluation of Its Effects. Chapel Hill: Institute of Government, University of North Carolina at Chapel Hill.

Clarke, S. H., and E. E. Gordon. 1997. "Public Sponsorship of Private Settling: Court-Ordered Civil Case Mediation.” Justice Systems Journal 19 (3): 311-39.

Clarke, S. H., E. Valente, Jr., and R. R. Mace. 1992. Mediation of Interpersonal Disputes: An Evaluation of North Carolina's Programs. Chapel Hill: Institute of Government, University of North Carolina.

Goerdt, A. J. 1992. "Small Claims Mediation in Three Urban Courts." In Small Claims and Traffic Courts: Case Management Procedures, Case Characteristics, and Outcomes in Twelve Urban Jurisdictions. Williamsburg, VA: National Center for State Courts.

Hann, R. G., and C. Barr. 2001. Evaluation of the Ontario Mandatory Mediation Program (Rule 24.1): Final Report-The First 23 Months. Simcoe, Canada: Ontario Ministry of the Attorney General.

Hedeen, T. 2004. "The Evolution and Evaluation of Community Mediation: Limited Research Suggests Unlimited Progress.” Conflict Resolution Quarterly 22 (1-2): 101-33.

Kobbervig, W. 1991. Mediation of Civil Cases in Hennepin County: An Evaluation. St. Paul, MN: Minnesota Judicial Center.

MacFarlane, J. 1995. Court-Based Mediation of Civil Cases: An Evaluation of the Ontario Court (General Division) ADR Centre. Windsor, Canada: University of Windsor. 
Maiman, C. R. 1997. An Evaluation of Selected Mediation Programs in the Massachusetts Trial Court. Boston, MA: Massachusetts Supreme Judicial Court.

Maryland Rules of Procedure. Title 17 - Alternative Dispute Resolution.

McAdoo, B., Welsh A. N., and Wissler L. R. 2003. "Institutionalization: What Do Empirical Studies Tell Us about Court Mediation?” Dispute Resolution Magazine, Winter, 8-10.

McEwen, A. C. 1992. An Evaluation of the ADR Pilot Project: Final Report. Brunswick, ME: Bowdoin College.

McEwen, A. C., and J. R. Maiman. 1981. "Small Claims Mediation in Maine: An Empirical Assessment." Maine Law Review 33: 237-68.

Pearson, J. 1982. “An Evaluation of Alternatives to Court Adjudication.” The Justice System Journal 7 (3): 420-44.

Pearson, J., and N. Thoennes. 1984. "Mediating and Litigating Custody Disputes: A Longitudinal Evaluation.” Family Law Quarterly 17 (4): 497-524.

Riskin, L. L. 1994, “Mediator Orientations, Strategies and Techniques," Alternatives to the High Cost of Litigation 12 (9): 111-14.

Schildt, K., J. J. Alfini, and P. Johnson. 1994. Major Civil Case Mediation Pilot Program, $17^{\text {th }}$ Judicial Circuit of Illinois: Preliminary Report. DeKalb, IL: Northern Illinois University College of Law.

Shack, J. 2003. "Efficiency: Mediation in Courts Can Bring Gains, But Under What Conditions?” Dispute Resolution Magazine 9 (2): 11-14.

Shack, J. E. 2007. Bibliographic Summary of Cost, Pace, and Satisfaction Studies of CourtRelated Mediation Programs, 2d ed. Chicago: Resolution Systems Institute. 
Shepherd, E. R. 1995. Neighborhood Dispute Settlement: An Evaluation Report of Neighborhood Dispute Settlement Center's Program with City of Harrisburg Bureau of Police - Executive Summary. Harrisburg, PA: Neighborhood Dispute Settlement Center of Dauphin County. Shestowsky, D. 2014. "The Psychology of Procedural Preference: How Litigants Evaluate Legal Procedures Ex Ante." Iowa Law Review 99 (2): 637-710.

Slack, L. 1996. A Comparative Analysis on the Benefits of Mediation in the Cobb County Superior Court. Williamsburg, VA: Institute for Court Management, National Center for State Courts.

Stipanowich, T. J. 2004. "ADR and the 'Vanishing Trial': The Growth and Impact of “Alternative Dispute Resolution.”' Journal of Empirical Legal Studies 1 (3): 843-912. Thoennes, N. 2000. "Dependency Mediation: Help for Families and Courts." Juvenile and Family Court Journal 51 (2): 13-22.

Tyler, T. R. 2006. Why People Obey the Law. Princeton, NJ: Princeton University Press.

Welsh, N. 2001. "Making Deals in Court-Connected Mediation: What's Justice Got to Do with It.” Washington University Law Quarterly 79 (3): 787-862.

Wissler, L. R. 1995. "Mediation and Adjudication in the Small Claims Court: The Effects of Process and Case Characteristics." Law \& Society Review 29 (2): 323-58.

Wissler, L. R. 2002. "Court-Connected Mediation in General Civil Cases: What We Know from Empirical Research." Ohio State Journal of Dispute Resolution 17 (3): 641-704.

Wissler, L. R. 2004. "The Effectiveness of Court-Connected Dispute Resolution in Civil Cases." Conflict Resolution Quarterly 22 (1-2): 55-88. 